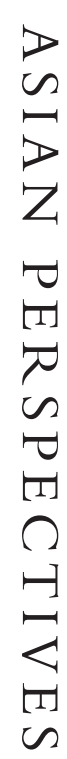

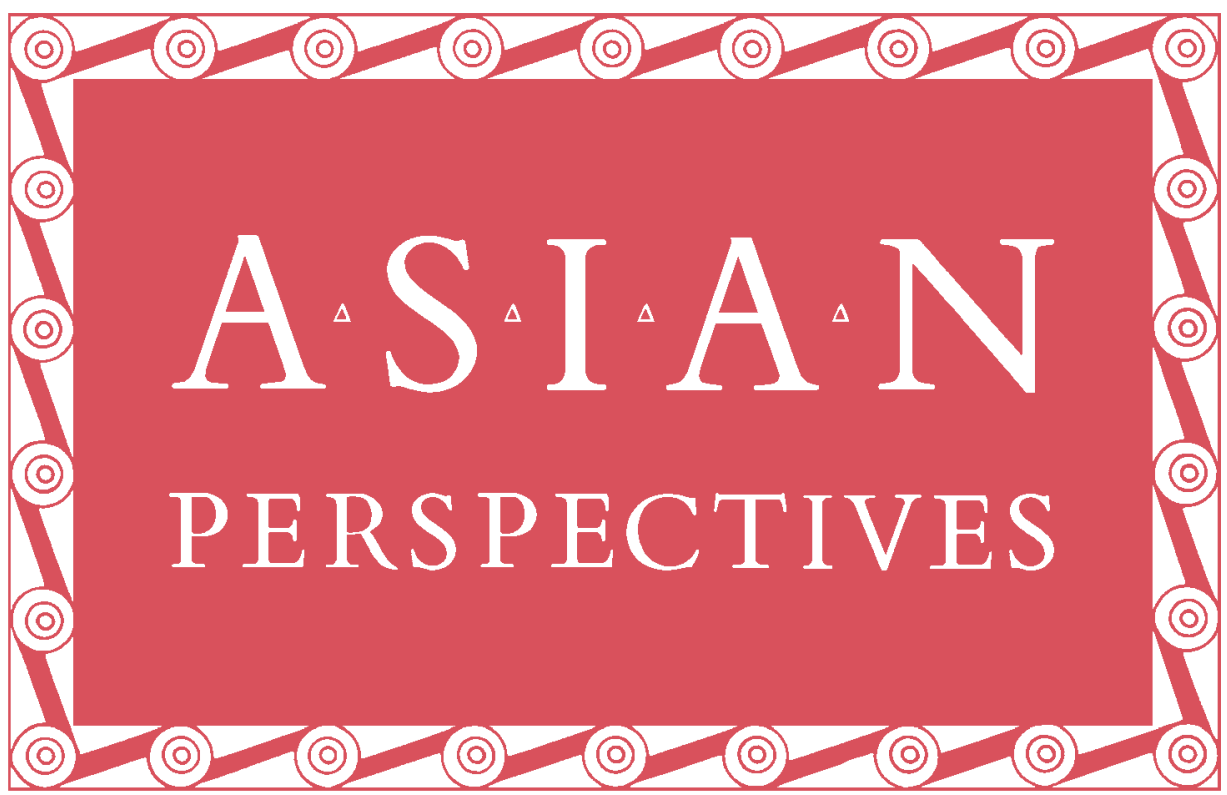

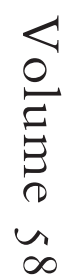

The Journal of Archaeology

for Asia and the Pacific

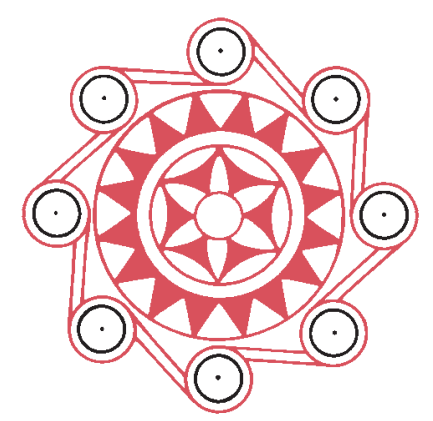

Volume 58 Number 22019 


\section{ASIAN PERSPECTIVES}

The Journal of Archaeology for Asia and the Pacific

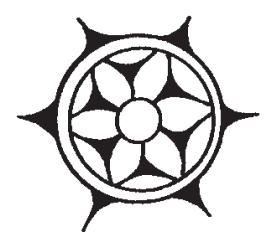

Editors' Note

ARTICLES

A Bioarchaeological Study of Trauma at Late Iron Age to

Protohistoric Non Ban Jak, Northeast Thailand

Lucille T. Pedersen, Kate M. Domett, Nigel J. Chang,

Siân E. Halcrow, Hallie R. Buckley, Charles F. W. Higham,

Dougald J. W. O'REILLY, and Louise SHEWAN

Austronesian Expansions and the Role of Mainland

New Guinea: A New Perspective

Glenn R. SUMmERHAYES

Ritual, Landscapes of Exchange, and the Domestication of

Canarium: A Seram Case Study

Roy ELLEN

Conflict and Identity: The Ritual of Wall Construction in

Early China

YANG Qian

Last-Millennium Settlement on Yadua Island, Fiji: Insights into

Conflict and Climate Change

Piérick C. M. Martin, Patrick D. Nunn, Niko TokaInavatu,

Frank THOMAS, Javier LEON, and Neil TINDALE

Household Ethnoarchaeology and Social Action in a

Megalith-Building Society in West Sumba, Indonesia

Ron L. ADAMS 
On Craft Production and the Settlement Pattern of the Jinsha Site Cluster on the Chengdu Plain

Kuei-chen LIN

BOOK REVIEWS

World Heritage Craze in China: Universal Discourse,

National Culture, and Local Memory

Reviewed by Magnus FISKESJÖ

Archaeology and Buddhism in South Asia

Reviewed by Lars FOGELIN

Yungang: Art, History, Archaeology, Liturgy

406

Reviewed by Denise Patry LEIDY

Khao Sam Kaeo: An Early Port-City between the Indian

Ocean and the South China Sea

Reviewed by Michèle H. S. DEMANDT

Women in Ancient China

Reviewed by Sheri A. Lullo 


\title{
A Bioarchaeological Study of Trauma at Late Iron Age to Protohistoric Non Ban Jak, Northeast Thailand
}

\author{
$\mathbf{\Delta} \cdot \mathbf{\Delta} \cdot \mathbf{\Delta}$ \\ Lucille T. Pedersen, Kate M. Domett, Nigel J. Chang, Siân E. Halcrow, \\ Hallie R. Buckley, Charles F. W. Higham, Dougald J. W. O'Reilly, and \\ Louise SHEWAN
}

\begin{abstract}
The Late Iron Age to early historic period site of Non Ban Jak (ca. fourth to eighth centuries A.D.), in the Upper Mun River Valley, northeast Thailand, provides one of the largest and best preserved skeletal samples from an important period of change in social and technological complexity in prehistoric Southeast Asia. This study assessed the patterning of individual-level trauma prevalence and long bone fracture rates in this community to determine the level of risk of injury and the possible relationship with cultural change. One quarter $(25.5 \%)$ of adults experienced antemortem or perimortem trauma. This level of trauma is high when compared to other Iron Age sites in the Southeast Asian region. Injury patterning suggests the majority of antemortem trauma is the result of accidental injury through occupational hazards and lifestyle activities. However, cranial injuries such as a depressed fracture, facial fractures, and perimortem sharp force trauma, as well as a possible parry injury and multiple trauma observed in some individuals, are indicative that at least a portion of the population had been engaged in interpersonal violence. This study emphasizes local variation. Non Ban Jak is one of only a few excavated sites that contributes to an understanding of the transition from the late Iron Age to the early protohistoric period in Thailand as well as the wider region in Southeast Asia. KeYwORDS: trauma, interpersonal violence, bioarchaeology, Iron Age, protohistoric period, Southeast Asia, northeast Thailand.
\end{abstract}

\section{INTRODUCTION}

THIS STUDY FOCUSES ON THE BIOARCHAEOLOGICAL AND ARCHAEOLOGICAL evidence for trauma and conflict in a single community in Upper Mun River Valley, northeast Thailand, that of Non Ban Jak, dated to A.D. 300-750 (Higham 2016a). Non Ban Jak is

Lucille T. Pedersen and Kate M. Domett are from the College of Medicine and Dentistry, James Cook University, Townsville, Australia. Nigel J. Chang is from the College of Arts, Society and Education, James Cook University, Townsville, Australia. Siân E. Halcrow and Hallie R. Buckley are from the Department of Anatomy, University of Otago, Dunedin, New Zealand. Charles F. W. Higham is from the Department of Anthropology \& Archaeology, University of Otago, Dunedin, New Zealand. Dougald J. W. O'Reilly is from the College of Arts and Social Sciences, Australian National University, Canberra, Australia. Louise Shewan is from the School of Earth Sciences, University of Melbourne, Australia. 
rare among excavated sites in mainland Southeast Asia because it contains one of the largest and best preserved skeletal samples straddling the transition from late prehistoric (later Iron Age) into the early historic or protohistoric period. Here we use the term 'Iron Age' holistically to encompass technological change, sociopolitical processes, and environmental landscapes (White 2017). The potential for intra- and intercommunity conflict to have existed during the Iron Age in Southeast Asia is strong because of the sociopolitical environment at the time; this period anticipated the appearance of early state society in the region. It has been argued that social change and the increased potential for violence can be driven by increasing population density and the intensification of agriculture in association with significant environmental changes such as unpredictable monsoon seasons and increased aridity and salt-affected soils (Boyd and Chang 2010; Domett et al. 2011; O'Reilly 2000). In support of this general theory of increased violence, Pietrusewsky and Douglas (2001) suggest that interpersonal conflict and violent trauma can be expected in prehistoric societies undergoing agricultural intensification and increased sedentism due to the need to protect territory and resources from competing populations.

Castillo and colleagues (2018) note that, from the beginning of the Iron Age deposits at the site, subsistence at Non Ban Jak appears to mark a final stage in a centuries-long transition from dryland rice farming to intensive wet rice farming in the Upper Mun River Valley. Importantly, human interments continued at Non Ban Jak for some 150 years later than nearby Iron Age sites such as Noen U-Loke and Ban Non Wat (Higham 2016a). Burials from such a late period are rarely found, especially as the Buddhist and Hindu religious practice of cremation was gaining popularity in the region at this time (Ward and Tayles 2016; Welch 1985). Thus, Non Ban Jak is ideally placed to examine questions of biocultural responses to subsistence change.

This study also examines the issue of variation in the trajectory of sociopolitical change between the regions of northeast Thailand and northwest Cambodia. In contrast to the large integrated polities that developed in the neighboring Mekong Delta and riverine area of central Thailand, the sites of northeast Thailand had limited exposure to maritime trade from China and India because of their inland positions (Higham 2016a). On the other hand, the upper layers of Non Ban Jak are rich in Dvaravati-related ceramics indicating clear connections to early central Thai states (Higham et al. 2014). Evidence from Non Ban Jak is here compared with the findings of Domett, O'Reilly, and Buckley (2011), who have presented the most definitive skeletal and archaeological evidence for interpersonal violence in mainland Southeast Asia at the site of Phum Snay, a Cambodian Iron Age community exposed to the rise of Angkorian state rule.

\section{DEFINING VIOLENCE}

To definitively determine the relationship between trauma and violent behaviour, a distinction must first be made between accidental and intentional sources of injury. In this article, contextual evidence and possible mechanisms of injury are examined to assess whether trauma was the result of a random unplanned and unexpected (i.e., accidental) incident; such accidents typically reflect interactions with the environment rather than human intentionality (Roberts 2000; Walker 2001). In contrast, violence is most often depicted as involving the intent to harm people by way of force or power; violence may result in injury, death, or negative psychological and health outcomes (Åström et al. 2002; Steinmetz 1986; Walker 2001; WHO 1996). 
How violence is conceptualized varies over time and between regions and communities due to heterogenous cultural and social factors, family values, and individuals (Harrod et al. 2012). Violence can thus manifest in many forms with different causes, including: domestic violence, interethnic raiding, or feuding (Harrod et al. 2012; Martin et al. 2010; Walker 2014); corporal punishment, organized warfare, or ritual fighting (Ocobock 2012; Scott and Buckley 2014; Torres-Rouff and King 2014); and massacre, homicide, sacrifice, cannibalism, torture, or genocide (Osterholtz 2012; Pijoan Aguadé and Lory 1997; Totten et al. 1997; Walker 2001).

Some forms of violence are so subtle that they are almost invisible in the skeletal record. The causes of such violence are intertwined with social structures (i.e., political and economic institutions) and policies that prevent marginalised subgroups of society from fully accessing resources and services that meet basic human needs (Martin and Harrod 2012; Shaffer 2017). These forms of violence may be evidenced in nonspecific indicators of physiological stress, however. For example, skeletal assessments of subgroup populations may show higher rates of infectious disease or malnutrition or increased infant mortality, suggesting inequity in access to resources. While such indicators of structural violence will be investigated in future studies on the Non Ban Jak sample, this article focuses on more overt evidence of violence in the form of skeletal trauma. The skeletal sample and archaeological context at Non Ban Jak provides an opportunity to interpret human behaviour during a period of intensive sociocultural and environmental change.

\section{ARCHAEOLOGICAL CONTEXT}

Before turning to osteological evidence for trauma, a deeper appreciation of the cultural context of the site is required. Non Ban Jak (NBJ) is located within the Upper Mun River catchment on the Khorat Plateau in northeast Thailand (Fig. 1). This is just one of a complex of sites that have been investigated in this region over the past four decades (Evans et al. 2016; Higham and Kijngam 2009; Higham et al. 2007; Higham and Thosarat 2005; O'Reilly 1998; Welch and McNeill 1988). Together, these investigations trace a local trajectory from the establishment of Neolithic communities in the Upper Mun River catchment (ca. mid-seventeenth century B.C.) to incorporation of the region into the Angkorian Empire (ca. mid-ninth century A.D.). Non Ban Jak represents a crucial, previously unexplored segment of this trajectory linking the late prehistoric with the early protohistoric period.

Non Ban Jak is the first large area excavation to expose pre-brick, plastered lime floor and wall structures that appear to be associated with this protohistoric period (Higham et al. 2014), although the first local indication for residential buildings was found at Non Muang Kao in the 1990s (O’Reilly 1998). These impressive constructions provide clear evidence of a major transformation in domestic technology and potentially in the sociopolitical relationships and structures of the community. Elaborate permanent structures that are rebuilt over time can represent the maintenance of social structure and occupational stability as well as the transmission of control over resources and territory from one generation of kin to the next (Bailey 1990).

Non Ban Jak is an elongated site measuring approximately $350 \times 180 \mathrm{~m}$. Two distinct main mounds rise up to five meters above the surrounding rice fields and form the eastern and western lobes of the site. The two mounds are linked by a lower saddle and the entire site is surrounded by two wide moats, increasing the total area to 


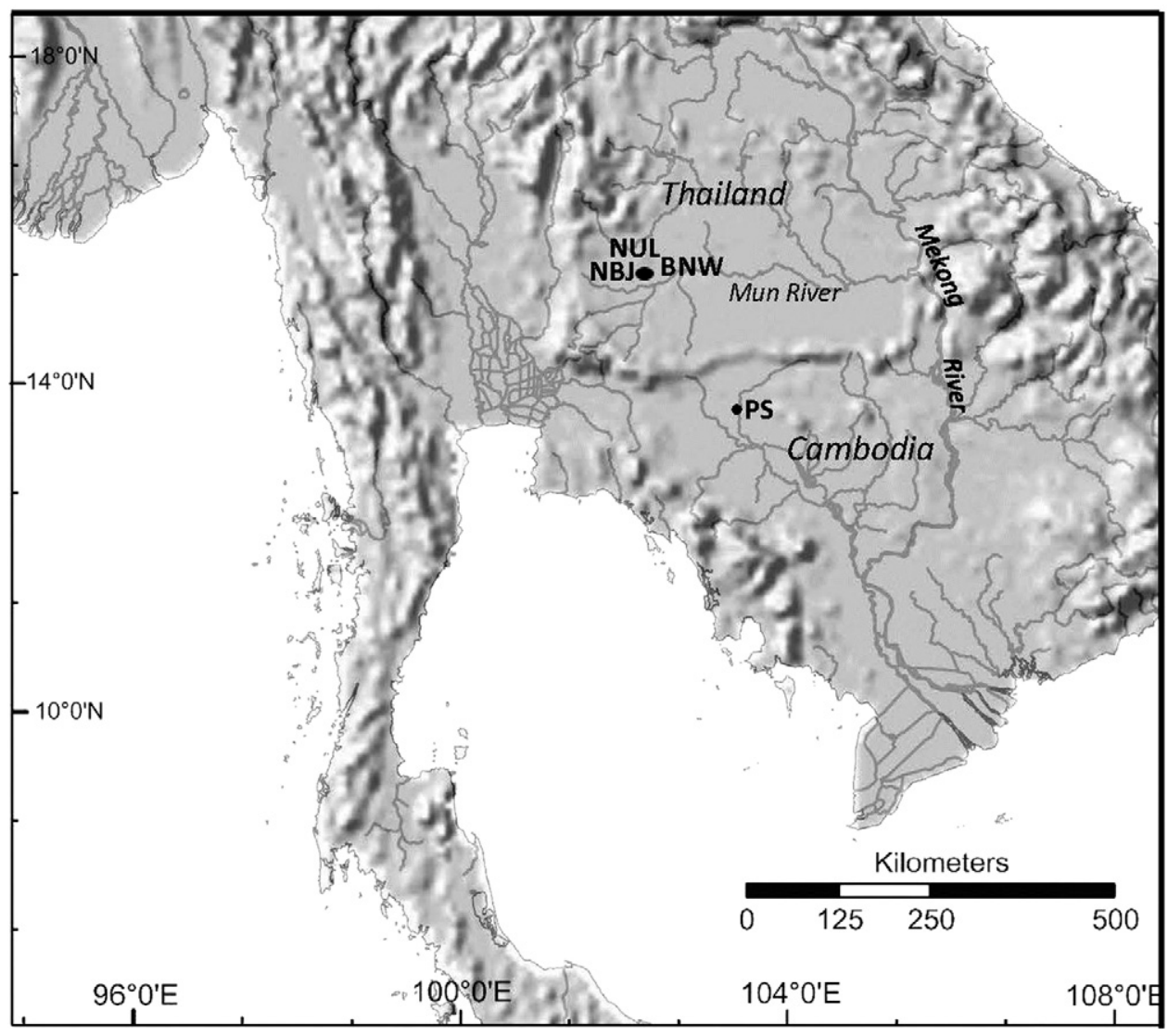

Fig. 1. Map of Southeast Asia indicating Iron Age sites included in this study: NBJ = Non Ban Jak; BNW $=$ Ban Non Wat; NUL = Noen U-Loke; PS = Phum Snay. (Map created by Kate Domett.)

approximately $530 \times 350 \mathrm{~m}$. Excavations spanning 2011 to 2018 were carried out in two locations $(\mathrm{B}, \mathrm{E})$ on the eastern mound and three locations $(\mathrm{A}, \mathrm{C}, \mathrm{D})$ on the western mound (Fig. 2). It appears that the eastern mound was almost completely constructed as a result of human activity, with the deepest archaeological evidence found near the level of surrounding present day rice fields. The archaeological deposits on the western mound are shallower, with a maximum depth of only around three meters. It seems likely that this was the location of the original natural mound on which the Iron Age occupation began in the early fourth century A.D. (Higham et al. 2014).

As noted above, large building structures, apparent lanes, and interments located in and around residential areas have been found on both mounds. The structures seem to be larger and more impressive on the eastern mound, where a deep stratigraphic sequence of overlying structures eventually gives way to a distinct and well-defined ancestral Iron Age cemetery some four meters below the surface of the mound. The stratigraphy appears more compressed on the western mound, where the 2017 


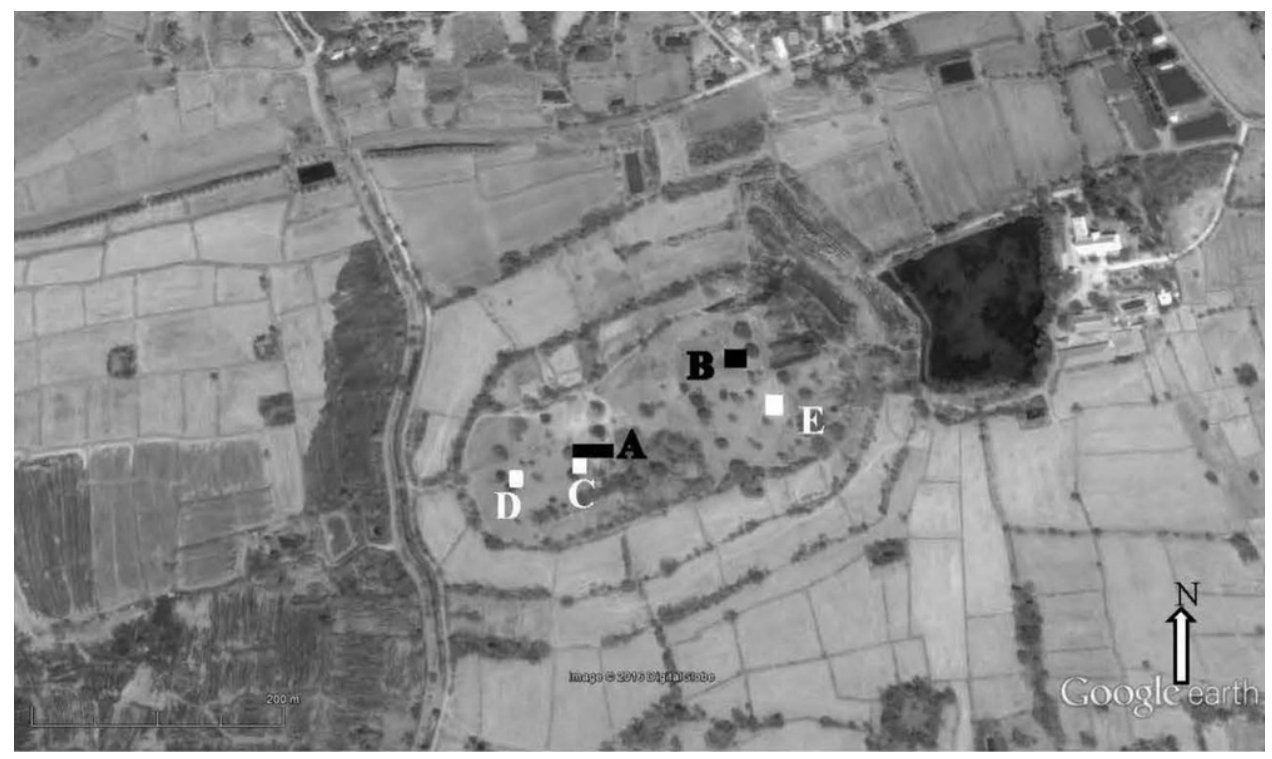

Fig. 2. Satellite image of Non Ban Jak site, showing 2011-2015 excavation areas (black) and 2016-2018 excavation areas (white) of the western mound (A, C, D) and eastern mound (B, E). (Map data: Google Earth, Digital Globe 2016.)

excavation season revealed evidence of an initial Neolithic occupation and the most recent excavations (January 2018) revealed Bronze Age pottery.

Alongside the impressive structural evidence, other features of the site indicate the presence of a level of economic and cultural innovation. In common with other large mounded sites in northeast Thailand, the well-developed moats and botanical evidence for intensive wet rice agriculture suggest significant and managed investment of energy and resources (Castillo et al. 2018; Higham et al. 2014). The presence of iron ploughshares and sickles has been argued to further support a major intensification of agricultural practices compared with the Bronze Age and early Iron Age in the region (Higham et al. 2014). Exotic glass beads, gold, silver, exotic semi-precious stones, and marine shells indicate long-distance exchange and presumably some differences in wealth (Higham et al. 2014). This is not a new trend, however, as extended trade networks are apparent in the wider region as early as the Neolithic period (Boyd and Chang 2010; Carter 2015; Higham et al. 2014). Probable sub-floor burials within domestic dwellings have been interpreted as a particular mortuary practice intended to strengthen kin-group or social affiliations; these burials further imply a significant change in social organization from earlier periods (Joyce 1999; Kuijt et al. 2011). It is also important to note that the upper layers at the site indicate clear associations with central Thai Dvaravati cultures. While no burials include distinctive Dvaravati-style high-fired earthenware, the site does appear to record continuous occupation from the mid and late Iron Age to the Buddhist state influenced culture in the region, immediately prior to more direct influence from Khmer Angkor (Evans et al. 2016; Murphy 2014). 


\section{THE HUMAN REMAINS}

Drawing on the above background archaeological data in conjunction with bioarchaeological data, we hypothesize that there will be more evidence of trauma on skeletal remains found at Non Ban Jak than has been documented for other sites in the region. We now consider the osteological evidence of trauma in the adult skeletal sample.

This study examines adult burials lifted from the eastern and western mounds during four excavation seasons from 2011 through 2015. From the 141 burials first identified on site plans (Higham et al. 2014), post-excavation analysis (excluding misidentified faunal remains and burials with no bones and merging two incomplete sets of skeletal remains into one) determined a total of 137 individuals had been excavated. The overall preservation of the bones is very good compared with other samples recovered for this period in Thailand. Just over a third $(N=53)$ of individuals were recorded as articulated and near complete ( $>75 \%$ of the skeleton present). Some burials were represented by just a few bone fragments, while others were partial skeletons with bones preserved in good condition.

Excavation reports on the site by Higham (2014) and Higham and colleagues (2014) provide a great deal of detail on occupation contexts, burial rituals, and mortuary plans. The reports revealed six cultural layers on the eastern mound and four on the western mound. Fourteen of the 137 individuals, including three adults and 11 subadults ( $<15$ years of age), were interred on the eastern mound (burials B1-B14) within layers two and five dating from the fifth century A.D.

Four mortuary phases (MP) containing 123 individuals (52 adults, 67 subadults, and 4 of indeterminate age) were identified in the cemetery located on the western mound, along with the remains of residential structures. The mortuary phases were distinguished by the relationship of burials to various occupational contexts within different stratigraphic layers. Higham and colleagues (2014) reported that adult burials were typically laid out supine, with an orientation to the north or south favored in the first mortuary phase; this orientation changed to NNW or SSE in the following three mortuary phases. Higham and colleagues (2014) also reported a probable secondary burial of an adult in MP1 interred in a flexed position. Most infant burials were interred within lidded ceramic vessels. A few infants were laid supine like the adults and some were buried with their head and feet within pots. Radiocarbon dates provided by Higham and colleagues (2014) indicate that burials from MP1 and MP2, contained in the lowest stratigraphic layers ( 3 and 4 ), were interred during the fourth to early sixth centuries; MP3 burials within layer 2 contexts were dated from the fifth through middle sixth centuries; and MP4 burials were located within layer 1 contexts (just below the present day surface) dated A.D. 600-800 (Higham 2016b).

\section{METHODS}

Age and sex estimations were carried out using the standards outlined in Buikstra and Ubelaker (1994). Metric analysis of long bone lengths and/or femoral and humeral head diameters were used for sex determination if the pelvis or skull were not available (Buikstra and Ubelaker 1994). Sex was then able to be assessed when individual measurements were compared to a range of prehistoric Thai samples (Domett, unpublished data) using section point analysis. Age-at-death of subadults ( $<15$ years) was estimated using the dental methods outlined by Halcrow and colleagues (2013). If 
an age-at-death of an adult was not able to be estimated using the pelvis or epiphyseal fusion, molar wear (Smith 1984) was seriated (Lovejoy 1985). Absolute age ranges for adults are unattainable in a prehistoric sample and so for this study age categories were broadly defined as subadult ( $<15$ years), young adult, mid age adult, and older adult.

Radiography was used to assist in identifying fracture type and degree of healing (Lovell 2008). Pathologies, such as trauma-induced degenerative joint disease or boneweakening disease such as osteoporosis, were noted to help identify any factors that may directly or indirectly affect the presence of fractures (Krakowka 2017; Lovell 1997). Macroscopic observations of abnormal displacement or dislocation of joints, sharp force trauma (SFT), and blunt force trauma (BFT) were also recorded. SFT was recorded using the cut mark morphology terminology described by Lewis (2008). Characteristics evaluated were linear lesions with well-defined sharp edges and a v-shaped cross section. The location, dimensions, number and orientation, and patterning of cuts were also noted. Cranial BFT was identified through observation of ectocranial deformations, linear fracture lines, and inward deformation of endocranial bone (Lovell 1997).

Antemortem injuries were recognized by evidence of active or completed bone remodeling (Lovell 1997). In contrast to postmortem damage in dry, brittle bone, fresh bone retains its organic viscoelastic properties, making it possible to diagnose perimortem injuries. The presence of bone adhering to the edges of the lesion, inner bevelling, and sharp edges is characteristic of perimortem injury, whereas dry bone tends to shatter on impact rather than fracture (Lovell 1997; Wheatley 2008).

\section{Statistical Analysis}

Whether represented by several bones or a complete skeleton, all individuals were examined for trauma (i.e., SFT, BFT, fracture, contusion, dislocation). Prevalence of trauma was calculated as the number of adult individuals with evidence for trauma divided by the total number of adult individuals in the sample. The rate of fractures in major long bone elements such as the clavicle, humerus, ulna, radius, femur, tibia, and fibula was also calculated (number of adult long bones with fractures divided by the number of complete adult long bones). For a long bone to be considered complete at least 75 percent of the element needed to be present; both left and right elements were included when present. This methodology allowed trauma prevalence and fracture rates to be compared with other studied Southeast Asian skeletal samples. Due to the small sample sizes, statistical analysis for significance was carried out using Fisher's Exact Tests (FET) with two-tailed $p$ value and a confidence interval of 95 percent. A significance level of 0.05 was used to assess whether there were notable differences either in trauma prevalence or fracture frequencies between samples.

\section{RESULTS}

\section{Demography}

The number of individuals currently analyzed is 137 , with subadults representing 56.9 percent (78 individuals), and adults 40.1 percent (55 individuals). Four burials (B53, B67, B88, B116) did not contain enough skeletal elements to be able to determine if they were subadults or adults (indeterminate age). The sample of 55 adults consists of 23 females, 18 males, and 14 individuals of indeterminate sex (Table 1). 
Table i. Sex and Age at Death Distribution of Non Ban JAK SAMPLE

\begin{tabular}{lcccrc}
\hline AGE & MALE & FEMALE & UNSEXED & TOTAL & $(\%)^{\mathrm{a}}$ \\
\hline Indeterminate & & & 4 & 4 & \\
Subadult $(<15$ years $)$ & & & 78 & 78 & \\
Young adult & 4 & 2 & 4 & 10 & $(18.2)$ \\
Mid-aged adult & 7 & 8 & 1 & 16 & $(29.1)$ \\
Older adult & 6 & 7 & 0 & 13 & $(23.6)$ \\
Adult & 1 & 6 & 9 & 16 & $(29.1)$ \\
Total adults & 18 & 23 & 14 & 55 & \\
$\%$ per sex & $(32.7)$ & $(41.8)$ & $(25.5)$ & & \\
Total all individuals & & & & 137 & \\
\hline
\end{tabular}

${ }^{a}$ Percent adult sample only.

${ }^{\mathrm{b}}$ Unable to estimate age.

Age at death estimation of the sample revealed ten young adults, 16 mid age adults, 13 older age adults, and 16 adults of indeterminate age.

\section{Trauma by Individual}

None of the 78 subadults examined in this study had evidence for trauma. A total of 14 adults (25.5\% of adult sample) (Table 2) had traumatic antemortem or perimortem lesions, the majority of which are fractures (Table 3). A total of 20 traumatic lesions (SFT and BFT) were observed, with four individuals each exhibiting two or more lesions (Fig. 3, Table 3). Three of the 20 lesions (SFT) were unhealed. There was no significant difference in the prevalence of trauma experienced by males $(5 / 18,27.8 \%)$ and females $(6 / 23,26.1 \%)(p$-value $=1.000)($ Table 2$)$.

\section{Fractures by Individual}

A total of 15 healed fractures were observed in 12 individuals: four males, six females and two of unknown sex (Table 3). There was a clavicle fracture and upper limb long bone fractures in four individuals and rib fractures in five individuals. Two individuals had cranial fractures. There were no fractures in the major lower limb bones and only two individuals showed evidence of toe phalanx fractures.

Table 2. Trauma Prevalence in Adults Classified by Sex

\begin{tabular}{lccccc}
\hline & \multicolumn{2}{c}{ Within AdUlt POPUlation } & & \multicolumn{2}{c}{ WITHIN EACH SEX CATEGORY } \\
\cline { 2 - 3 } \cline { 5 - 6 } \cline { 5 - 6 } & \multicolumn{1}{c}{$n / \mathrm{N}^{\mathrm{A}}$} & $\%$ & & $n / N$ & $\%$ \\
\hline Male & $5 / 55$ & 9.1 & & $5 / 18$ & 27.8 \\
Female & $6 / 55$ & 10.9 & & $6 / 23$ & 26.1 \\
Unsexed & $3 / 55$ & 5.5 & & $3 / 14$ & 21.4 \\
Total & $14 / 55$ & 25.5 & & $14 / 55$ & 25.5 \\
\hline
\end{tabular}

${ }^{a} n=$ number of individuals exhibiting one or more traumatic lesions; $N=$ number of adults. 


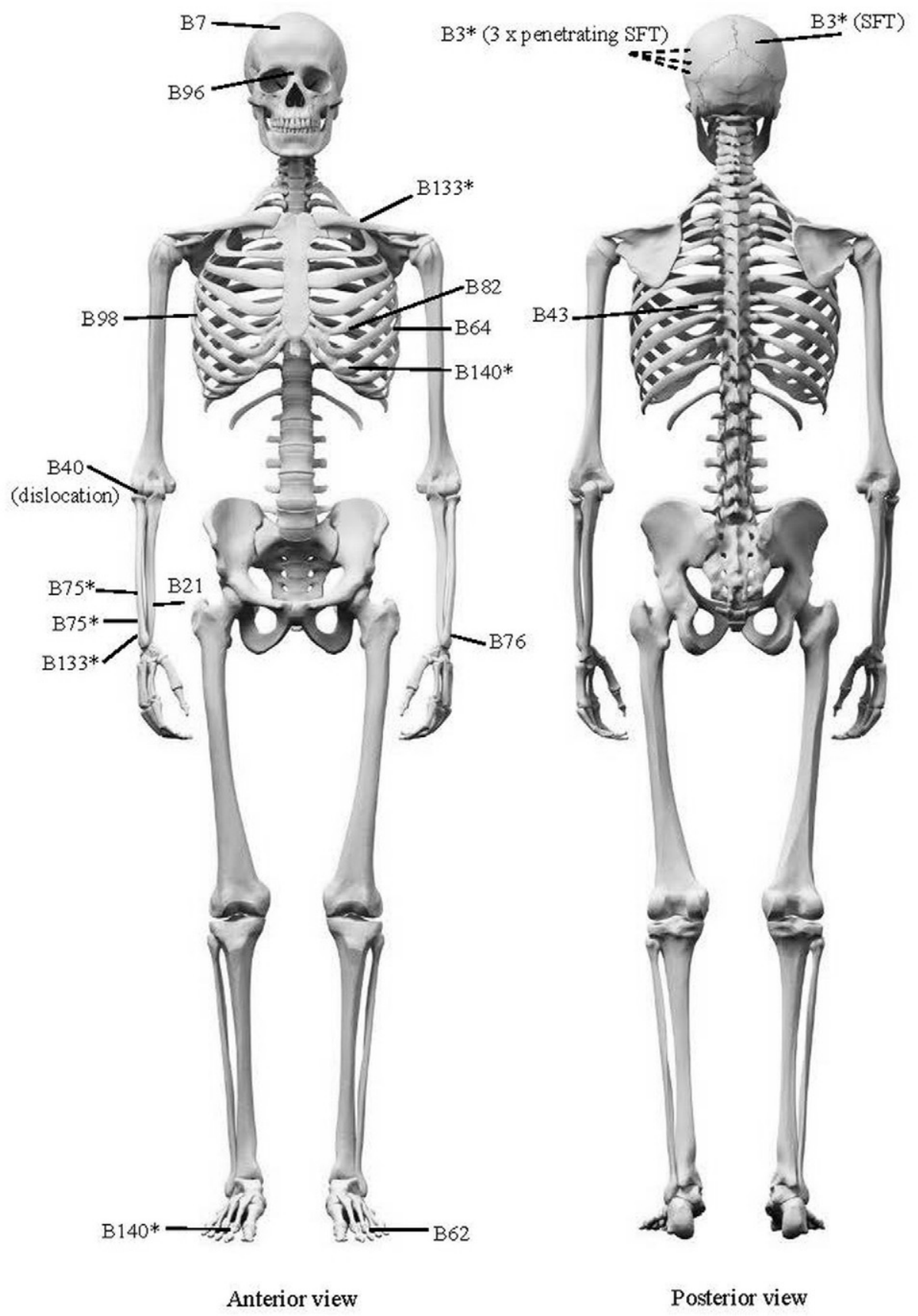

Fig. 3. Location of antemortem and perimortem trauma in NBJ adults. All lesions are fractures except where indicated otherwise; $*$ asterisk indicates individuals with more than one lesion; dashed line indicates possible perimortem trauma (skeleton photos from Getty Images, iStock.com/Leonello Cavatelli 2011). 
Table 3. Adult Trauma by Individual

\begin{tabular}{|c|c|c|c|c|c|}
\hline BURIAL NO. & ADULT AGE & ELEMENT & SIDE & PART & TRAUMA $^{\mathrm{a}}$ \\
\hline \multicolumn{6}{|l|}{ Males } \\
\hline \multirow[t]{2}{*}{3} & \multirow[t]{2}{*}{ Young } & Cranium & $\mathrm{R}$ & Parietal - posterior & SFT (shallow cut) \\
\hline & & Cranium & $\mathrm{L}$ & Parietal - lateral & $\begin{array}{l}\text { SFT }(3 \times \text { piercing cuts, } \\
\text { perimortem?) }\end{array}$ \\
\hline 21 & Mid & Ulna & $\mathrm{R}$ & Distal $1 / 3$ & Fracture (transverse) \\
\hline 62 & Mid & Toe phalanx & $\mathrm{L}$ & Distal epiphysis & Fracture (oblique) \\
\hline 82 & Older & Rib & $\mathrm{L}$ & Shaft & Fracture (malaligned) \\
\hline 96 & Adult & Cranium & $\mathrm{L} / \mathrm{R}$ & Nasals/frontal processes & Fracture \\
\hline \multicolumn{6}{|l|}{ Females } \\
\hline 7 & Older & Cranium & $\mathrm{R}$ & Frontal bone & Depressed fracture \\
\hline 43 & Young & Middle rib & $\mathrm{L}$ & Posterior shaft & Fracture (non-union) \\
\hline 64 & Older & Lower rib & $\mathrm{L}$ & Lateral shaft & Fracture (non-union) \\
\hline \multirow[t]{2}{*}{75} & \multirow[t]{2}{*}{ Older } & Radius & $\mathrm{R}$ & Distal $1 / 3$ & Fracture (transverse) \\
\hline & & Radius & $\mathrm{R}$ & Distal $1 / 3$ & Fracture (transverse) \\
\hline 76 & Older & Radius & $\mathrm{L}$ & Distal $1 / 3$ & Fracture (transverse) \\
\hline \multirow[t]{2}{*}{133} & \multirow[t]{2}{*}{ Mid } & Clavicle & $\mathrm{L}$ & Shaft & Fracture (transverse) \\
\hline & & Radius & $\mathrm{R}$ & Distal 1/3 & Fracture (transverse) \\
\hline \multicolumn{6}{|l|}{ Unknown sex } \\
\hline 40 & Adult & Humerus & $\mathrm{R}$ & Distal epiphysis & Radial dislocation \\
\hline 98 & Adult & Rib & $\mathrm{R}$ & Lateral shaft & Fracture (transverse?) \\
\hline \multirow[t]{2}{*}{140} & \multirow[t]{2}{*}{ Adult } & Lower (?) rib & $\mathrm{L}$ & Anterior shaft & Fracture (transverse) \\
\hline & & Toe phalanx & $\mathrm{R}$ & Distal epiphysis & Fracture (oblique) \\
\hline
\end{tabular}

${ }^{\text {a }}$ All trauma healed unless noted otherwise

Table 4. Adult Long Bone Fracture Rate (\% By Bone Element)

\begin{tabular}{|c|c|c|c|c|c|c|c|c|}
\hline \multirow[b]{2}{*}{ ELEMENT } & \multicolumn{2}{|c|}{ MALE } & \multicolumn{2}{|c|}{ FEMALE } & \multicolumn{2}{|c|}{ ?SEX } & \multicolumn{2}{|c|}{ ADULTS } \\
\hline & $n / N^{a}$ & $\%$ & $n / N$ & $\%$ & $n / N$ & $\%$ & $n / N$ & $\%$ \\
\hline Clavicle & $0 / 29$ & 0.0 & $1 / 17$ & 5.9 & $0 / 23$ & 0.0 & $1 / 69$ & 1.4 \\
\hline Humerus & $0 / 27$ & 0.0 & $0 / 22$ & 0.0 & $0 / 28$ & 0.0 & $0 / 77$ & 0.0 \\
\hline Radius & $0 / 27$ & 0.0 & $4 / 16^{b}$ & 25.0 & $0 / 14$ & 0.0 & $4 / 57^{b}$ & 7.0 \\
\hline Ulna & $1 / 28$ & 3.6 & $0 / 16$ & 0.0 & $0 / 16$ & 0.0 & $1 / 60$ & 1.7 \\
\hline Femur & $0 / 23$ & 0.0 & $0 / 22$ & 0.0 & $0 / 20$ & 0.0 & $0 / 65$ & 0.0 \\
\hline Tibia & $0 / 24$ & 0.0 & $0 / 19$ & 0.0 & $0 / 23$ & 0.0 & $0 / 66$ & 0.0 \\
\hline Fibula & $0 / 22$ & 0.0 & $0 / 17$ & 0.0 & $0 / 23$ & 0.0 & $0 / 62$ & 0.0 \\
\hline Total & $1 / 180$ & 0.6 & $5 / 129^{b}$ & 3.9 & $0 / 147$ & 0.0 & $6 / 456^{b}$ & 1.3 \\
\hline
\end{tabular}

${ }^{a} n=$ number of fractures to element; $N=$ number of total complete $(\geq 75 \%)$ elements.

${ }^{\mathrm{b}}$ One individual has 2 fractures to same radius. 
Table 4 shows the long bone fracture rates. A total of six healed long bone fractures were recorded in the 456 complete long bones analyzed (1.3\%). Females frequently displayed more long bone fractures than men, with 3.9 percent $(5 / 129)$ of female long bones and 0.6 percent of male long bones $(1 / 180)$ affected. This difference did not quite reach statistical significance (FET $p$-value $=0.0857$ ).

\section{Long Bone Fracture Rates}

Most of the long bone fractures (5/6) affected the forearm (Table 3, Table 4). Four of the forearm fractures were on the right side and all five were located in the distal third (Table 3). The adult long bone fracture rates indicate the radii were more commonly affected $(7.0 \%, 4 / 57)$ than the ulnae $(1.7 \%, 1 / 60)$. All radial fractures were in females. One woman (B75) suffered two healed fractures to the right radius; one fracture was slightly proximal to the first, but due to the advanced level of bone remodeling in both fractures, it is unknown if these were the result of one event. The single ulnar fracture was in a mid age adult male (B21). The healed transverse fracture of the distal right ulna had slight posterior displacement of the distal element. B76, an old age female, was observed to have had a distal fracture to her left radius.

Only one individual, a female adult (B133), was observed with a fractured left clavicle (1.4\%, 1/69 by bone element). When compared with the contralateral clavicle, shortening and deformity of the injured clavicle was evident (Fig. 4). This female also had a distal fracture to her right radius. A male adult (B62) and an adult of unknown sex (B140) each exhibited an isolated oblique fracture to a toe phalanx.

\section{Rib Fractures}

Due to the fragmentary nature of ribs, prevalence is reported per individual rather than by element. Rib fractures were experienced by 9.1 percent of the adults $(5 / 55)$. Within the female sample, 8.7 percent $(2 / 23)$ of individuals were observed with rib fractures, compared to 5.6 percent of males $(1 / 18)$ and 14.3 percent of unsexed adults $(2 / 14)$. There was no statistically significant difference between the sexes (FET $p$-value $>0.99$ ). All but one of the rib fractures were on the left side. Most rib fractures showed complications. B43, a young adult female, exhibited a transverse fracture of a possible eighth rib. This rib had been ossified to what is possibly the seventh rib at the posterior medial angle (Fig. 5). An older adult female (B64) sustained a complete mid-shaft fracture with nonunion of a lower rib (likely tenth or eleventh) (Fig. 6). B82, an older adult male, has a malaligned complete rib fracture, but it cannot be ascertained which rib it is or the exact location on the shaft where the fracture occurred. B98, an adult of undetermined sex and age, has a well-remodeled fracture of a right, possibly upper, rib.

\section{Dislocation}

Burial 40, an adult of indeterminate sex and age, was the only individual to exhibit a dislocation. The radial fossa of the right humerus was enlarged, probably resulting from an anterior radial dislocation. The radius was not present.

\section{Cranial Trauma}

Cranial trauma was observed in two males and one female in the sample, with a frequency of 11.5 percent $(3 / 26)$ of adult individuals with at least 75 percent of the 


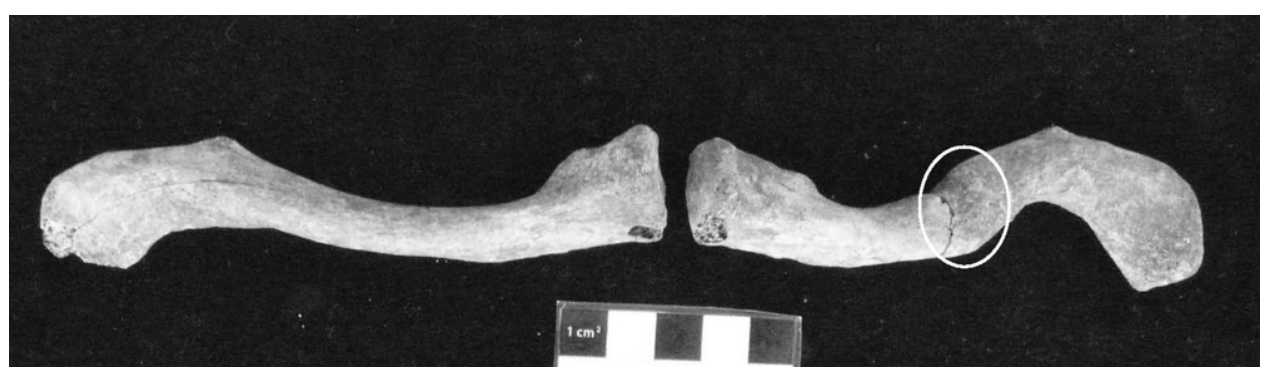

Fig. 4. NBJ B133 superior view of right clavicle (left) and shorter left clavicle (right) due to healed fracture (circled).

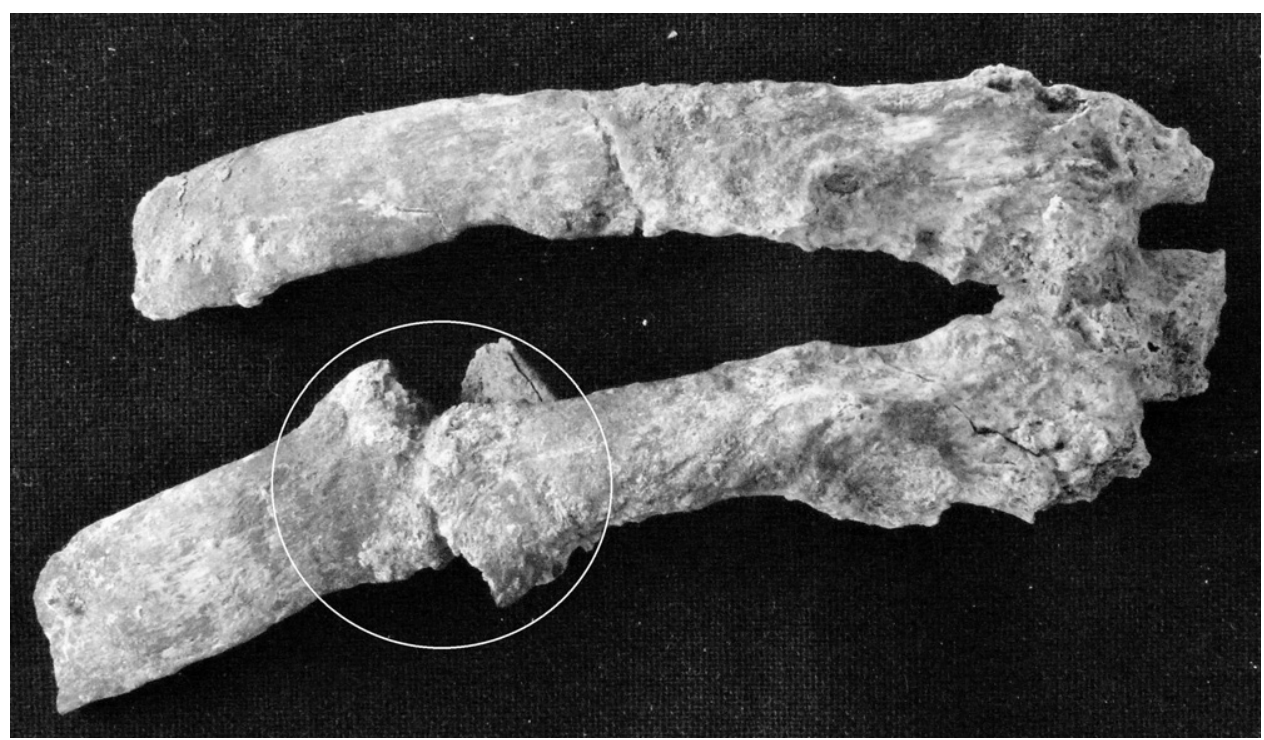

Fig. 5. NBJ B43 external view of two left ribs ankylosed by antemortem ossification; non-union fracture circled on rib 8.

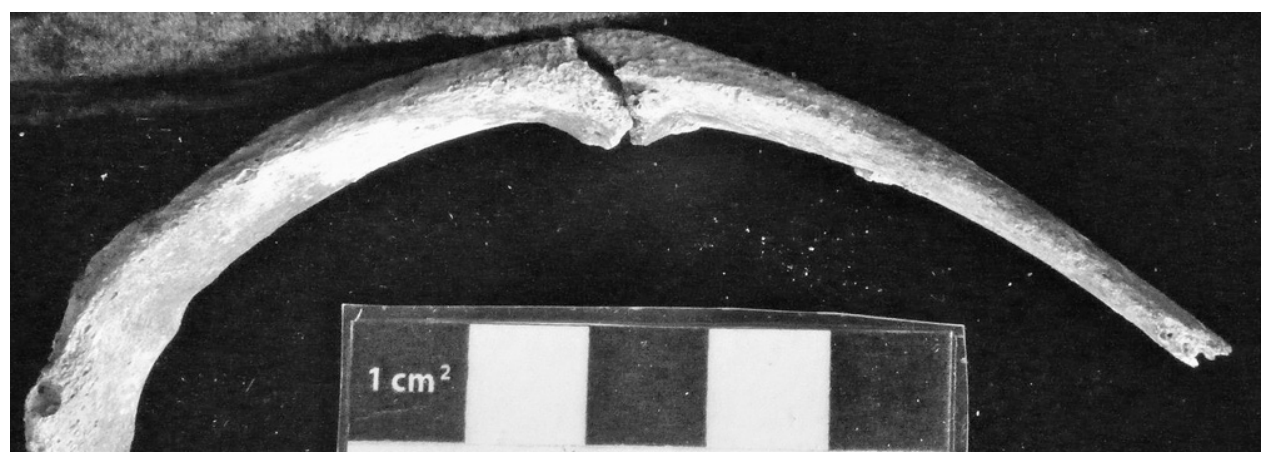

Fig. 6. NBJ B64 inferior view of left rib (10 or 11) with non-union fracture. 


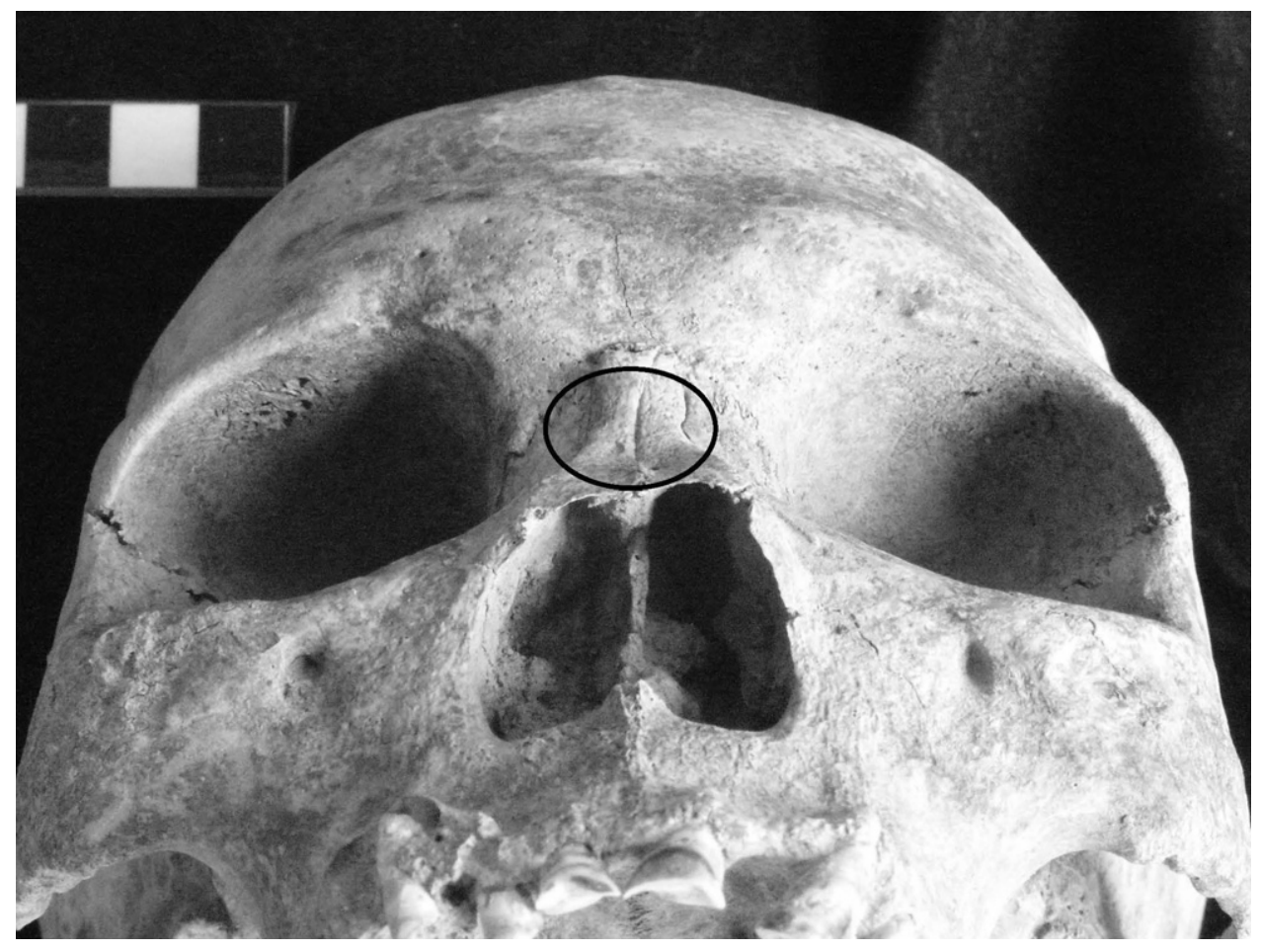

Fig. 7. NBJ B96. Healed depressed fracture (within black circle) affecting left and right nasal bones and frontal processes of maxillae.

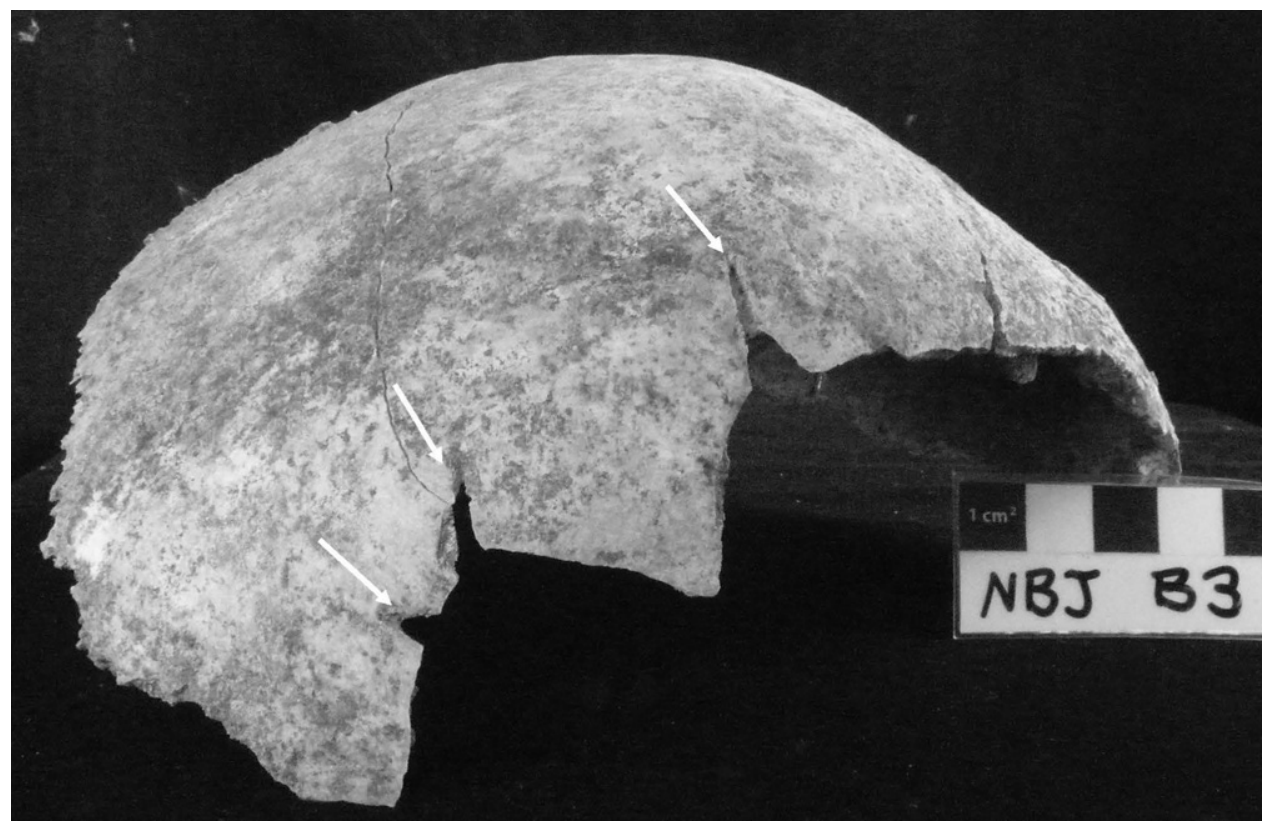

Fig. 8. NBJ B3. Lateral view of left parietal with three unhealed cuts (white arrows); coronal suture located at left edge of cranial fragment. 
cranium present. There were no individuals presenting with both cranial and postcranial trauma. An older age adult female (B7), had a remodeled circular depression fracture on the right frontal bone. A male of indeterminate age (B96) had healed blunt force trauma to the left and right frontal processes and nasal bones (Fig. 7). A young adult male (B3) had cut marks to the cranial vault; a healed cut was located on the right parietal and three unhealed cuts pierced completely through the left parietal bone (Fig. 8).

\section{DISCUSSION}

Before we can interpret our findings, the likely causes of the trauma in the burial sample at Non Ban Jak need to be established. This can be attempted on an individual basis where the type of fracture to the skeleton suggests the mechanism of injury (Lovell 2008). As outlined above, the skeletal evidence can then be considered in the biocultural context of the sample (Martin and Harrod 2012; Scott and Buckley 2014; Walker 2001).

\section{Mechanism of Injury}

In both prehistoric and modern populations, depressed skull fractures, fractures to facial bones, and fractures of the distal ulna are commonly associated with violent interpersonal conflict, especially if multiple injuries occur from a single incident (Brink et al. 1998; Jurmain et al. 2009; Milner et al. 2015; Ślaus et al. 2012; Walker 1989). The nasal fracture in B96 could have been caused during face-to-face combat, as could the distal ulna fracture in B21. Transverse fractures to the distal ulna without radial involvement, such as that experienced by B21 (a male adult), are often reported as a possible parry fracture; this direct-force injury occurs when the arm is brought up to protect the face from a blow (Judd 2008; Richards and Deal 2014). However, accidental injury such as that which results from falling against a sharp edge, is another possible mechanism for this fracture (Judd 2008). In an archaeological setting, the cause is particularly difficult to discern when there are no other injuries present in the individual.

Differentiating the cause (accident or violence) of cranial trauma may be suggested by the location of the injury relative to the "hat brim line" (HBL), defined as the level that a hat brim would lie (from the top of the eyebrows to the occipital pole at the rear) (Ehrlich and Maxeiner 2002). Forensic case studies of cranial trauma reviewed by Kremer and colleagues (2008) indicate that injuries above the HBL are more indicative of violent attack than an accidental fall, especially if located on the left side (from a right-handed attacker) and associated with multiple lacerations (repeated blows to the head). Two of the Non Ban Jak individuals (B3 and B7) with cranial trauma had either a depressed fracture (right side) or multiple cut marks (left side) above the HBL that could be indicative of intentional violence rather than accident.

The presence of both antemortem and multiple perimortem cranial SFT lesions in B3 (adult male) suggests he was involved in two separate attacks, the latter of which possibly resulted in death from associated shock or hemorrhage (or other unknown soft tissue injury). The posterolateral location of the injuries suggest he was attacked from behind. These injuries may have been inflicted with iron implements such as a knife, spear head, point, sickle, or machete; all these items are found as mortuary offerings at 
this site (Higham 2016b; Higham et al. 2014). Inter-community conflict is also possible as iron spears, knives, and points were uncovered from Iron Age burials of nearby Noen U-Loke and Ban Non Wat (Higham 2011b, 2016a).

The cranial injury in B7, the only such cranial or facial injury of an adult female at Non Ban Jak, is evidence of healed blunt force trauma to the right forehead. This may have been the result of an accidental injury sustained from a fall or perhaps a direct blow from a falling object (Walker 1989). The injury could also have been intentionally caused by a hammer-blow from a fist, a thrown rock, or a blunt weapon from a lefthanded attacker in face-to-face conflict (Walker 1989). Baked clay pellets used as projectiles for hunting bows or slingshots have been recovered from Iron Age burials in Thailand (Coupey 2006; Gorman and Charoenwongsa 1976; Higham 2011a). Such implements could also have caused a depressed skull fracture.

Some studies report that transverse fractures of long bones are more likely to be caused by direct violent attack, while oblique fracture lines are indicative of the indirect non-torsional force typical of accidents (Grauer and Roberts 1996). Long bone fractures at Non Ban Jak are predominantly transverse (Table 3). Transverse fractures to the distal radius (B75, B76, B133) are clinically described as a Colles' fracture; these are commonly caused by a fall onto an outstretched hand (Sigurdardottir 2014). The etiology of these fractures could be accidental or violence-related. For example, a fall after a violent push from an attacker could lead to a forearm fracture that looks the same skeletally as one resulting from tripping over uneven ground and putting an arm out to catch oneself. This highlights the difficulty of assigning an etiology of traumatic injury in limb bones. Osteoporosis is a risk factor that can predispose older age females to Colles' fracture; however, no overt signs of osteopenia have been observed in the sample to date.

The etiology of clavicle fractures is subject to similar issues as the other long bones. Clinical studies suggest clavicle fractures are most frequently the result of a fall directly onto the shoulder or a direct blow (Nowak et al. 2000; Nunn et al. 1989). One female (B133) at Non Ban Jak experienced a mid-shaft left clavicle fracture and a Colles' fracture to her right radius; both injuries could have resulted from a single accidental fall.

Rib fractures were evident in 9.1 percent of adult individuals $(N=5)$. A review of rib fracture mechanisms by Lovell (2008) included stress fractures induced by habitual activities, blunt force trauma to the chest from a fall from a height or onto an object, or receiving a blow to the thorax from an animal, person, or object. There is some preliminary evidence that suggests three of the individuals (B43, B64, B133) with rib fractures at Non Ban Jak had other pathology (i.e., mixed lytic and reactive lesions in the spine and sacroiliac joints) that suggest an underlying pathological condition leading to increased susceptibility to fracture. Two women (B43, B64) had non-union of their rib fractures; this may have resulted in on-going pain and discomfort, exacerbated by the movement of the rib ends during physical activity or coughing (Nirula et al. 2009).

Two Non Ban Jak individuals (B62, B140) had a fractured foot phalanx each. This type of fracture can result from depression forces, such as when the foot is crushed by a heavy object dropped from above or trampled by a large animal, or axial forces from stubbing a toe; though less common, stress fractures and a fall from a height are also possible causes of this fracture (Hatch and Hacking 2003; Van Vliet-Koppert et al. 2011). 


\section{Gender and Trauma}

Non Ban Jak males had only slightly higher (statistically insignificant) trauma prevalence compared to females; however, the risk of violent etiology was slightly elevated for males. Craniofacial sharp force trauma, a possible parry fracture, and blunt force trauma were observed in one younger male (B3), one mid age male (B21), and a male of indeterminate age (B96), respectively, whereas only one female (B7), of older age, experienced cranial trauma. In both modern and archaeological contexts, men, especially young and mid age adults, are reported to be more likely than women to receive trauma to these bones during violent encounters (Milner et al. 2015; Norris 1992; Owens 2007; Roksandic et al. 2006; Walker 1989). A number of factors could have contributed to these few violent injuries, including kin-group rivalry, male competition, intercommunity conflict, or interpersonal abuse. Given that the majority of Non Ban Jak individuals survived their injuries, another possibility is that trauma may have resulted from ritualized conflict or intermittent skirmishes where the intent was to injure rather than to kill (Scott and Buckley 2014). However, there is no direct evidence of such cultural practices during this period in this region.

This study found that women at Non Ban Jak were more susceptible to distal radii (i.e., Colles' fracture), clavicle, and rib fracture than men, with the fracture prevalence for radii being significantly higher in women $(p=0.015)$. The sex differences in long bone fracture rates could be due to differences in behaviour and gender roles in society or bone mass. Women's roles in an agricultural society have traditionally been associated with domestic tasks including child rearing, food production, and collecting firewood and water (Judd and Roberts 1999; Lovell 1997). However, with the intensification of agriculture, both sexes at Non Ban Jak were likely involved in strenuous labor such as rice planting and processing and animal husbandry, all of which could have resulted in the fractures to the ribs, clavicles, toes, and even forearms seen in both sexes at Non Ban Jak (Judd and Roberts 1999). Traditionally, males are reported to have greater involvement in high-risk and physically demanding activities than women (Judd and Roberts 1999; Lovell 1997; Milner et al. 2015). Candidates for such activities at Non Ban Jak include salt production, working with ploughs and draft animals, and construction of moats and buildings. Such heavy levels of physical activity would likely increase men's bone strength and thus reduce their susceptibility to bone fractures from falls (Milner et al. 2015; O'Neill et al. 1996).

Low bone mass is a risk factor for Colles' fractures in women pre- and postmenopause (Hung et al. 2005; Kanterewicz et al. 2002). However, there is currently no evidence of bone mass deterioration in the Non Ban Jak sample. Gender differences in bone shape or micro-architecture may also explain differences in fracture prevalence between men and women (Goulding et al. 2000).

Mortuary treatment and trauma patterns representative of gendered violence was not present at Non Ban Jak. In studies of prehistoric groups where females have been found to be victims of gendered social violence such as slavery, abduction for forced marriage, or spousal abuse, such individuals are often reported to have had abnormal burial treatment and skeletal trauma patterns indicative of their treatment as a sub-class in society. This was the scenario Martin (2008) described for the site of La Plata Valley, Mexico, where three times more cranial trauma was recorded for females than males. Postcranial lesions among a sub-set of predominantly reproductive age women suggested a life of hard labor, poor health, and multiple non-lethal attacks 
(Martin 2008). The normal mortuary treatment at La Plata was for individuals to be placed in flexed or semi flexed positions inside storage pits or buildings (Martin 2008), but females with cranial trauma were observed to be buried with less care, usually placed in disused pits and with no mortuary goods, with their bodies either loosely flexed or lying face downwards or with their limbs awkwardly sprawled (Martin et al. 2008; Martin et al. 2010). A high frequency of violent craniofacial injury in reproductive-age females is argued to be evidence that spousal abuse was normalized in a number of prehistoric societies worldwide (Lessa and Souza 2006; Tung 2014; Wilkinson and Van Wagenen 1993).

Although some degree of female-directed violence at Non Ban Jak cannot be ruled out, neither the pattern of trauma nor the archaeological evidence are consistent with a pattern of gendered violence. Only two females $(2 / 23,8.7 \%)$ and one male $(1 / 18$, $5.6 \%)$ at Non Ban Jak were observed with multiple lesions and no females or males were observed with a combination of both cranial and postcranial trauma. Cranial injuries were not observed in either of the two reproductive-age women (a mid age adult and a young adult) affected by trauma. The trauma type and patterning suggest that the majority of injuries experienced by females likely had an accidental etiology. Men and women received similar mortuary treatment and there is no evidence of an obvious disparity in health between the sexes that would suggest an imbalance in access to resources. Whatever environmental and sociopolitical stresses this population faced, there is no evidence that it translated into entrenched social violence.

\section{Biocultural Context and Trauma}

Paleoenvironmental evidence from the Khorat Plateau indicates a decline in moisture from the mid-second century B.C., with increasing dryness and low seasonal rainfall between the first and eighth centuries A.D. affecting dry rice production; this corresponds with the Iron Age occupation of Non Ban Jak (Boyd 2008; Boyd and McGrath 2001; Castillo et al. 2018; Wohlfarth et al. 2016). Coping mechanisms for environmental change in northeast Thailand included the construction of moats around mounded sites in the Mun River Valley, including at Non Ban Jak. Archaeobotanical remains of wetland weed species within some rice deposits suggests that an agricultural change to wet rice farming was firmly established by the late Iron Age (Castillo et al. 2018; Higham et al. 2014). The moats would have allowed for the management of water for wet rice agriculture and the potential for the creation of a rice surplus that may have had significant sociopolitical implications (Castillo et al. 2018; King et al. 2014; O'Reilly 2014). This change in subsistence strategy likely led to an increased risk of injury from moat excavation, land clearance activities such as tree felling, and direct contact with water buffalo pulling ploughs in rice paddies. Clinical studies on modern rural populations show that farming (i.e., production and management of domesticated plants and animals) is one of the most injury-prone occupations, with falls and animal-related trauma consistently rated as the most probable causes of observed lesions (Murphy et al. 2010; Virtanen et al. 2003; Xiang et al. 2000).

There is archaeological evidence for large animals being corralled and domesticated in Iron Age communities in the Khorat Plateau (Higham 1998, 2016a), with a subsequent increased consumption of meat (King et al. 2014; King et al. 2013). Trampling incidents are particularly associated with long bone fractures, head and chest trauma, and crushing injuries to toes (Murphy et al. 2010; Watts and Meisel 
2011). The evidence for trauma at Non Ban Jak shows a number of these types of injuries, including rib and toe fractures and BFT to the cranium.

\section{Trauma in the Iron Age: A Comparison within the Upper Mun River Valley}

The Iron Age and subsequent transition to the early historic period in Southeast Asia are particularly important periods of sociopolitical change. Communities were faced with and needed to respond to significant changes in their natural and cultural environments (Boyd and Chang 2010; Evans et al. 2016; Eyre 2010; Higham 2016a; Onsuwan 2008; O’Reilly 2014; White 1995). Three prehistoric sites within the Upper Mun River Valley include skeletal material dated to within the Iron Age (Table 5). Noen U-Loke and Ban Non Wat are settlements located within $10 \mathrm{~km}$ to the east of Non Ban Jak and share similar mortuary goods and burial rituals (Higham 2014, 2016a). This enables a comparison of trauma and associated cultural patterns in the southern part of the Khorat Plateau. However, this comparison is limited by the poorly preserved skeletal material from Noen U-Loke, where less than a third of the burials were complete and some burials were devoid of bone due to a chemical reaction with unthreshed rice included in the mortuary ritual (Tayles et al. 2007). The fragile and sometimes concreted or crushed nature of much of the Iron Age skeletal assemblage from Ban Non Wat also resulted in limiting observation of trauma (Kate Domett and Nancy Tayles, pers. comm. 2016).

With these limitations in mind, it is evident that each skeletal sample experienced a different risk of injury. Non Ban Jak has the highest proportion of individuals with recorded injuries (Tables 6 and 7). Given the close geographical proximity of the three sites, situated close to the edge of the floodplain and forested areas (King et al. 2014), it is possible that the variation in trauma was influenced by variations in sociopolitical organization rather than by risks from the natural environment. Non Ban Jak is the youngest of the three sites and thus may record a later stage in the transition from prehistory to history. This is most clearly seen in the scale and quality of town planning and residential structures seen at Non Ban Jak, which have not been observed at Noen U-Loke or Ban Non Wat (Higham 2016a). The process of change may also be

Table 5. Iron Age Sites Used for Comparison

\begin{tabular}{|c|c|c|c|c|c|}
\hline SITE & REGION $^{\mathrm{a}}$ & DATE OF IA BURIALS & INDIVIDUALS $^{\mathrm{b}}$ & ADULTS $^{c}$ & COMPLETENESS AND PRESERVATION \\
\hline Non Ban Jak & NET & A.D. $300-$ A.D. $750^{\mathrm{d}}$ & 137 & 55 & $\begin{array}{l}>1 / 3 \text { complete individuals, good } \\
\text { preservation }\end{array}$ \\
\hline Ban Non Wat & NET & 420 B.C.-A.D. $450^{\mathrm{e}}$ & 193 & 143 & $\begin{array}{l}\text { Poorly preserved bones, many } \\
\text { fragmented, very fragile }\end{array}$ \\
\hline Noen U-Loke & NET & 450 B.C. - A.D. $600^{f}$ & 120 & 67 & $\begin{array}{l}<1 / 3 \text { complete individuals, many } \\
\text { fragmented, fragile }\end{array}$ \\
\hline Phum Snay & NWC & 350 B.C.-A.D. $200^{\mathrm{g}}$ & 160 & 148 & $\begin{array}{l}\text { Majority of burials heavily } \\
\text { disturbed, good bone } \\
\text { preservation }\end{array}$ \\
\hline
\end{tabular}

${ }^{\mathrm{a}} \mathrm{NET}=$ northeast Thailand; NWC = northwest Cambodia.

${ }^{\mathrm{b}}$ Includes adults, subadults ( $\leq 15$ years), individuals of indeterminate age.

${ }^{c}$ Adults used for comparison in this study.

Date sources: ${ }^{\mathrm{d}}$ Higham 2016a; ${ }^{\mathrm{e}}$ Higham and Higham 2009; ${ }^{\mathrm{f}}$ Higham and Rispoli 2014; ${ }^{\mathrm{g}}$ Domett and Buckley 2012. 
Table 6. Trauma Prevalence in Adults by Individual in Iron Age Southeast Asia

\begin{tabular}{|c|c|c|c|c|c|c|c|c|}
\hline \multirow[b]{2}{*}{ SITE } & \multicolumn{2}{|c|}{ MALE } & \multicolumn{2}{|c|}{ FEMALE } & \multicolumn{2}{|c|}{ UNSEXED } & \multicolumn{2}{|c|}{ ADULTS } \\
\hline & $n / N^{a}$ & $\%$ & $n / N$ & $\%$ & $n / N$ & $\%$ & $n / N$ & $\%$ \\
\hline Non Ban Jak ${ }^{\mathrm{b}}$ & $5 / 18$ & 27.8 & $6 / 23$ & 26.1 & $3 / 14$ & 21.4 & $14 / 55$ & 25.5 \\
\hline Ban Non Wat ${ }^{\mathrm{c}}$ & $1 / 51$ & 2.0 & $1 / 49$ & 2.0 & $1 / 43$ & 2.3 & $3 / 143$ & 2.1 \\
\hline Noen U-Loke ${ }^{\mathrm{d}}$ & $1 / 21$ & 4.8 & $2 / 27$ & 7.4 & $1 / 19$ & 5.3 & $4 / 67$ & 6.0 \\
\hline Phum Snay ${ }^{\mathrm{e}}$ & $20 / 63$ & 31.7 & $12 / 65$ & 18.5 & $7 / 20$ & 35.0 & $39 / 148$ & 26.4 \\
\hline
\end{tabular}

${ }^{a} n=$ number of individuals affected by trauma; $N=$ number of observed individuals.

Data sources: ${ }^{b}$ Present study; ${ }^{c}$ Domett and Tayles (pers. comm. 17 June 2016); ${ }^{\mathrm{d}}$ Tayles et al. 2007; 'Domett et al. 2011; Domett and O'Reilly 2009.

indicated at the slightly earlier site of Noen U-Loke, where Higham (2016a) noted that several clusters of wealthier burials contained exotic mortuary goods during Iron Age phase 3. The fact that some social groups at this site had greater access to exotic goods than others may have set up conditions for (potentially violent) conflict both within the community and between communities as suggested by Higham (2016a). Although there were very few traumatic injuries identified in the poorly preserved bones of Noen U-Loke (4/67 adults, 6.0\%), and no long bone fractures, several injuries suggest interpersonal violence was present in the community (Table 7). One adult male had two healed depressed cranial fractures and another was possibly killed by the iron projectile point found in situ between his vertebrae (Higham and Thosarat 2007). Tayles (2003) also provided an in-depth case study of the possible murder of an elderly woman who experienced severe sharp and blunt force perimortem cranial trauma that, if it occurred antemortem, likely resulted in her death. Compared with Non Ban Jak and Ban Non Wat, this sample contains the most evidence for violence-induced trauma; such evidence correlates with the proliferation of iron points at Noen U-Loke (Higham 2002).

Preliminary data for Iron Age burials at Ban Non Wat indicate that the community's overall trauma prevalence was relatively low (2.1\%), with no Iron Age individuals experiencing cranial trauma and only one ulna fractured (Table 6). Given the large

Table 7. Adult Long Bone Fracture Rate (\% by bone element) of Iron Age Southeast Asian Sites

\begin{tabular}{|c|c|c|c|c|c|c|c|c|c|c|}
\hline \multirow[b]{2}{*}{ ELEMENT } & \multicolumn{2}{|c|}{ NON BAN JAK } & \multicolumn{2}{|c|}{ BAN NON WAT } & \multicolumn{2}{|c|}{ NOEN U-LOKE } & \multicolumn{2}{|c|}{ PHUM SNAY } & \multicolumn{2}{|c|}{ TOTAL } \\
\hline & $n / N^{a}$ & $\%$ & $n / N$ & $\%$ & $n / N$ & $\%$ & $n / N$ & $\%$ & $n / N$ & $\overline{\%}$ \\
\hline Clavicle & $1 / 69$ & 1.4 & $0 / 122$ & 0.0 & $0 / 44$ & 0.0 & $3 / 52$ & 5.8 & $4 / 287$ & 1.4 \\
\hline Humerus & $0 / 77$ & 0.0 & $0 / 97$ & 0.0 & $0 / 59$ & 0.0 & $0 / 70$ & 0.0 & $0 / 303$ & 0.0 \\
\hline Radius & $4 / 57$ & 7.0 & $0 / 95$ & 0.0 & $0 / 45$ & 0.0 & $2 / 24$ & 8.3 & $6 / 221$ & 2.7 \\
\hline Ulna & $1 / 60$ & 1.7 & $1 / 100$ & 1.0 & $0 / 45$ & 0.0 & $0 / 26$ & 0.0 & $2 / 231$ & 0.9 \\
\hline Femur & $0 / 65$ & 0.0 & $0 / 108$ & 0.0 & $0 / 66$ & 0.0 & $0 / 76$ & 0.0 & $0 / 315$ & 0.0 \\
\hline Tibia & $0 / 66$ & 0.0 & $0 / 108$ & 0.0 & $0 / 64$ & 0.0 & $0 / 60$ & 0.0 & $0 / 298$ & 0.0 \\
\hline Fibula & $0 / 62$ & 0.0 & $0 / 88$ & 0.0 & $0 / 48$ & 0.0 & $0 / 21$ & 0.0 & $0 / 219$ & 0.0 \\
\hline Total & $6 / 456$ & 1.3 & $1 / 718$ & 0.1 & $0 / 371$ & 0.0 & $5 / 329$ & 1.5 & $12 / 1874$ & 0.6 \\
\hline
\end{tabular}

${ }^{\mathrm{a}} n=$ number of fractures to element; $N=$ number of total complete $(\geq 75 \%)$ elements. 
sample size of complete long bones, this is likely to be an accurate reflection of low risk to skeletal trauma in the community during this period (Table 7). However, the bioarchaeological record neither captures the full extent of injuries (i.e., most soft tissue injuries) experienced by a population nor enables us to discern individuals that might have been killed in distant conflicts and not brought back for burial at the settlement. Ban Non Wat provides information particularly relevant to the beginning of the Iron Age. Although the people of this period participated in moat maintenance and farming associated with animals and rice agriculture (Higham 2011b, 2013), the prevalence of injury was not high, perhaps in part due to less exposure to intensive wet-rice agriculture (Castillo et al. 2018).

In comparison with both these sites, the trauma prevalence at Non Ban Jak was high (14/55 individuals, $25.5 \%)$, as was the long bone fracture rate (6/456 elements, $1.3 \%)$ (Tables 6 and 7). The results are suggestive of a riskier lifestyle when compared to other near-contemporaneous sites in the Upper Mun River Valley. Burials continued at Non Ban Jak for some 150 years longer than at Ban Non Wat and Noen U-Loke; mortuary evidence at the latter sites stops around A.D. 450 and A.D. 600 respectively (Higham 2016a; Higham and Higham 2009). Calibrated radiocarbon dates indicate that the majority of adult individuals affected by trauma $(13 / 45,28.9 \%)$ at Non Ban Jak were from contexts dating from ca. A.D. 300 through 600 (Higham et al. 2014). The crucial couple of centuries at the end of the Iron Age was a particularly intensive period of sociopolitical change for the Upper Mun River Valley of northeast Thailand in the pre-Angkorian period, which would have exposed the population of Non Ban Jak to changing living conditions. However, it is also interesting to note that only 10 percent of adults $(1 / 10)$ from the final mortuary phase (after A.D. 600) were observed with trauma. This apparent reversal in the trend of increasing trauma over time could be a function of sampling. It may also indicate a more peaceful hiatus prior to Angkorian incursions, perhaps related to developing relationships with the Dvaravati culture of central Thailand (Evans et al. 2016; Murphy 2014). Investigations of more sites dating to the late first-millennium A.D. are clearly required.

There is archaeological evidence for small-scale iron metallurgy being conducted at Non Ban Jak, Noen U-Loke, and Ban Non Wat (Duke et al. 2010; Higham 2016a; Higham et al. 2014). This activity may have contributed to an increased risk of injury associated with the heavy manual labor required for processing ore and metalsmithing. Lovell (2008) indicates that there is an increased risk of fracture for participants in activities such as carrying heavy loads of water and firewood. Manual labor involved in the construction and maintenance of buildings and multiple moats and banks at these sites would also have come with risk of injuries such as the fractures to a proximal ulna, metacarpal, and rib observed in the Ban Non Wat sample and the tibial contusion and thoracic vertebra wedge fracture in the Noen U-Loke sample (Appendix A1, A2).

The observed perimortem cranial trauma at Noen U-Loke and Non Ban Jak suggest that lethal intent was evident and that at least some Upper Mun River Valley individuals experienced serious physical violent trauma. Protohistoric inscriptions from northern Cambodia offer details of military excursions up the Mun River into northeast Thailand by members of the first small pre-Angkorian states that were established in the Mekong River region (Higham and Thosarat 1998; Vickery 1998). It is possible that this led to skirmishes with local settlements, but there is no evidence for large scale conflict in the Upper Mun River Valley during this period. 
In direct contrast, no other Iron Age site has such convincing and extensive evidence of large scale violence as at Phum Snay in northwestern Cambodia, occupied from 350 B.C. to A.D. 200 (Domett et al. 2011). This site had the highest individual trauma prevalence in adults (26.4\%) (Table 6), although it was only marginally higher than that recorded at Non Ban Jak (25.5\%). However, as reported by Domett, O'Reilly, and Buckley (2011), the patterning of trauma at Phum Snay presents a very different pattern than at Non Ban Jak, since it predominantly consisted of healed and perimortem blunt and sharp force trauma and depression fractures to crania (Appendix A3). Individuals at Phum Snay were buried with more weaponry than at any site in Thailand (O'Reilly et al. 2004). Males were often buried with long swords and several burials contained caches of iron points and military paraphernalia (Domett et al. 2011). The time and energy expended in producing these weapons and the severity of trauma suggests that this settlement was engaged in combat over a period of time, possibly to defend its independence in an environment of considerable political friction among the hierarchical societies of the emerging Angkorian kingdom (Domett et al. 2011). Our observations at Non Ban Jak clearly need to be seen in relation to Phum Snay in that any observed trend towards more trauma in the Upper Mun River Valley likely reflects a subtle process as part of a distinctly divergent trajectory when compared to the more strictly martial society observed at Phum Snay.

\section{CONCLUSION}

The high rate of trauma in the burial sample from Non Ban Jak indicates that this population faced a greater risk of injury compared with others in the Upper Mun River Valley region. The majority of injuries to forearm bones, clavicle, ribs, and toes at Non Ban Jak appear to have an accidental etiology. Although there was no statistically significant difference in trauma prevalence between the sexes, the injury pattern suggests there may have been gender differences in occupation and activities. The majority of female trauma was likely associated with falls, while males suffered slightly more head trauma that likely had a violent etiology. Accidental trauma may be the result of more intensive land management practices required in an increasingly arid environment, including a more industrial and hazardous approach to agriculture and animal husbandry. However, the patterning of injuries in a few individuals (craniofacial trauma and parry fracture) suggests that at least some members of the community experienced interpersonal violence, perhaps consistent with intra- or intercommunity conflict related to changing social organization and conditions resulting from increasing population density and the proliferation of weapons production.

Conflict could also have resulted from increasing contact with early complex polities that developed locally or were expanding into the Mun River Valley from elsewhere. However, when we compare the trauma in Non Ban Jak to that in the martial society of Phum Snay, it is clear that there is less evidence for violence at Non Ban Jak and interpersonal violence was more incidental than common place. Whatever military excursions pre-Angkorian state-like polities were directing into the Upper Mun River Valley from the sixth century A.D., they had not resulted in direct conflict with the Non Ban Jak population. Later periods of occupation at Non Ban Jak were strongly influenced by Dvaravati culture and it may be that a closer search for influence from that direction during the final Iron Age mortuary phases will be revealing. 
Future work at Non Ban Jak and the broader region will build on this study to determine what pressures and opportunities led to differing trauma patterns in late Iron Age communities across mainland Southeast Asia. Focusing on the potential variety in the mosaic of local sociopolitical developments will lead to a more detailed understanding of people and society, at local and regional levels, on the eve of state formation in mainland Southeast Asia.

\section{ACKNOWLEDGEMENTS}

The excavations of Non Ban Jak were funded under a grant from the Australian Research Council 2011-2013 (DP110101997) led by Dougald O'Reilly and Louise Shewan, as well as a University of Otago Research Grant (2015) and Royal Society of New Zealand Marsden Fund (UOO1508/2016-2019), awarded to Hallie Buckley, Charles Higham, and Siân Halcrow. We would like to acknowledge the in-field support given by Jack Wood, Tara Thara, Wilbert Yee, Christina Sewall, Sam Sewall, Helen Bauer, Vickie Jarvis, Roger Prior, and Gay Stryker. Finally, the skilled team of local excavators continue to be invaluable to the mission of uncovering ancient Thailand.

Appendix A: Iron Age Trauma by Site and Individual

A.1 BAN NON WAT

\begin{tabular}{lclcll}
\hline BURIAL NO. & SEX & \multicolumn{1}{c}{ ELEMENT } & SIDE & \multicolumn{1}{c}{ PART } & \multicolumn{1}{c}{ TRAUMA } \\
\hline 333 & M & Ulna & L & Proximal 1/3 & Fracture (oblique?) \\
540 & F & 5th metacarpal & R & Distal 1/3 & Fracture \\
575 & $?$ & Rib & R & Shaft & Fracture \\
\hline
\end{tabular}

? = unknown side.

Source: Domett and Tayles (pers. comm. 17 June 2016).

A. 2 NOEN U-LOKE

\begin{tabular}{lclcll}
\hline BURIAL NO. & SEX & ELEMENT & SIDE & PART & TRAUMA \\
\hline 42 & M & Cranium & R & Parietal & Depressed fracture \\
& & Cranium & $?$ & Frontal & Depressed fracture \\
78 & $?$ & Tibia & L & Shaft & Contusion \\
99 & F & Skull & L \& R & Frontal & SFT (perimortem) \\
& & Cranium & R & & BFT (perimortem) \\
108 & F & T12 vertebra & & Body & Fracture (wedge) \\
\hline
\end{tabular}

? = unknown sex or side; $\mathrm{BFT}=$ blunt force trauma; $\mathrm{SFT}=$ sharp force trauma; $\mathrm{T} 12=12$ th thoracic vertebra.

Source: Tayles et al. 2007. 
A.3 PHUM SNAY

\begin{tabular}{|c|c|c|c|c|c|}
\hline BURIAL NO. & SEX & ELEMENT & SIDE & PART & TRAUMA \\
\hline PS01B6 & M & Clavicle & $\mathrm{R}$ & Midshaft & Fracture \\
\hline PS01B9 & $\mathrm{F}$ & Metacarpal & ? & Midshaft & Fracture \\
\hline PS03B7 & $\mathrm{F}$ & Clavicle & $\mathrm{R}$ & Midshaft & Fracture \\
\hline PS03B13 & $\mathrm{F}$ & 4th metacarpal & $\mathrm{R}$ & Midshaft & Fracture \\
\hline PSL4 & ? & Mandible & ? & Condyle & ?fracture \\
\hline PSL10 & M & Frontal & $\mathrm{R}$ & Midline & BFT \\
\hline PSL11 & $\mathrm{F}$ & Parietal & $\mathrm{R}$ & Posterior & SFT \\
\hline PSL16 & M & Frontal & $\mathrm{R}$ & Midline & SFT \\
\hline \multirow[t]{2}{*}{ PSL17 } & \multirow[t]{2}{*}{ M } & Frontal & $\mathrm{R}$ & Posterior & $\mathrm{BFT}$ - perimortem \\
\hline & & Frontal & $\mathrm{R}$ & $?$ & $\begin{array}{l}\text { SFT (penetrating?) - } \\
\text { perimortem }\end{array}$ \\
\hline WBC6 & M & Orbit & $\mathrm{R}$ & & SFT? (penetrating?) \\
\hline WBC8 & $\mathrm{M}$ & Frontal & $\mathrm{R}$ & Superior & BFT \\
\hline WBC29 & M & Frontal & $\mathrm{L}$ & Posterior & BFT \\
\hline WBC30 & M & Parietal & $\mathrm{L}$ & Posteriosuperior & SFT \\
\hline WBC32 & M & Parietal & $\mathrm{L}$ & Posterior & BFT \\
\hline WBC35 & M & Parietal & $\mathrm{R}$ & $?$ & BFT \\
\hline \multirow[t]{2}{*}{ WBC36 } & \multirow[t]{2}{*}{$\mathrm{M}$} & Frontal & $\mathrm{L}$ & Lateral & SFT \\
\hline & & Parietal & $\mathrm{R}$ & Posterior & SFT \\
\hline WBC38 & M & Parietal & $\mathrm{L}$ & Posterior & BFT \\
\hline WBC56 & M & Parietal & $\mathrm{R}$ & Posterior & SFT \\
\hline \multirow[t]{2}{*}{ WBC80 } & \multirow[t]{2}{*}{$\mathrm{M}$} & Parietal & $\mathrm{R}$ & Posterior & BFT \\
\hline & & Frontal & $\mathrm{R}$ & Anterior & BFT \\
\hline WBC88 & M & Parietal & $\mathrm{L}$ & Posterior & SFT \\
\hline \multirow[t]{2}{*}{ WLC10 } & \multirow[t]{2}{*}{$\mathrm{M}$} & Parietal & $\mathrm{L}$ & Posterior & BFT \\
\hline & & Frontal & $\mathrm{R}$ & Midline & BFT \\
\hline WLC95 & $\mathrm{M}$ & Parietal & $\mathrm{R}$ & Superior & BFT \\
\hline WLC96 & M & Parietal & $\mathrm{L}$ & Posterior & BFT \\
\hline WLC105 & M & Parietal & $\mathrm{R}$ & Posteriosuperior & BFT \\
\hline \multirow[t]{2}{*}{ WLC108 } & \multirow[t]{2}{*}{$\mathrm{M}$} & Parietal & $\mathrm{R}$ & Posterior & BFT \\
\hline & & Parietal & $\mathrm{L}$ & Anterior & SFT \\
\hline WBC10 & $\mathrm{F}$ & Parietal & $\mathrm{L}$ & Superiomedial & BFT \\
\hline WBC66 & $\mathrm{F}$ & Parietal & $\mathrm{R}$ & Posterior & SFT \\
\hline WBC70 & $\mathrm{F}$ & Parietal & $\mathrm{R}$ & Superior & SFT \\
\hline \multirow[t]{2}{*}{ WBC75 } & \multirow[t]{2}{*}{$\mathrm{F}$} & Parietal & $\mathrm{R}$ & Posteriosuperior & BFT \\
\hline & & Frontal & $\mathrm{L}$ & Anterior & SFT \\
\hline WBC82 & $\mathrm{F}$ & Glabella & ? & & $\begin{array}{l}\mathrm{BFT}-\text { perimortem } \\
(\text { Continued })\end{array}$ \\
\hline
\end{tabular}


Appendix A: (Continued)

\begin{tabular}{lcllll}
\hline BURIAL NO. & SEX & ELEMENT & SIDE & \multicolumn{1}{c}{ PART } & \multicolumn{1}{c}{ TRAUMA } \\
\hline WLC73 & F & Parietal & L & $?$ & SFT - perimortem \\
& & Parietal & L & $?$ & SFT - perimortem \\
& & Parietal & R & Predominantly R side & SFT - perimortem \\
& & Occipital & L & $?$ & SFT - perimortem \\
WLC75 & F & Parietal & L & Posterior & SFT \\
WLC91 & F & Parietal & L & Posterior & SFT \\
WBC18 & $?$ & Clavicle & L & Shaft, lateral & Fracture \\
WBC77 & $?$ & Frontal & R & Lateral & SFT \\
WBC81 & $?$ & Parietal & R & Posterior & BFT \\
WBM28 & $?$ & Mandible & $?$ & Condyle & ?fracture \\
WBR4 & $?$ & Radius & R & Distal epiphysis & Fracture \\
WBR6 & $?$ & Radius & R & Distal epiphysis & Fracture (angulation) \\
\hline
\end{tabular}

$?=$ unknown sex, side or part; BFT = blunt force trauma, SFT = sharp force trauma.

Source: Domett and O'Reilly 2009; Domett et al. 2011.

\section{REFERENCES CITED}

Åström, Sture, Gösta Bucht, Martin Eisemann, Astrid Norberg, and Britt-Inger Saveman 2002 Incidence of violence towards staff caring for the elderly. Scandinavian Journal of Caring Sciences 16(1):66-72.

Bailey, Douglass W.

1990 The living house: Signifying continuity, in The Social Archaeology of Houses: 19-48, ed. R. Samson. Edinburgh University Press.

BOyd, William E.

2008 Social change in late Holocene mainland SE Asia: A response to gradual climate change or a critical climatic event? Quaternary International 184(1):11-23.

Boyd, William E., ANd Nigel Chang

2010 Integrating social and environmental change in prehistory: A discussion of the role of landscape as a heuristic in defining prehistoric possibilities in northeast Thailand, in Altered Ecologies: Fire, Climate and Human Influence on Terrestrial Landscapes: 273-297, ed. S. Haberle, J. Stevenson, and M. Prebble. Terra Australis 32. Canberra, ACT: ANU E Press.

Boyd, William E., and Roger J. McGrath

2001 Iron Age vegetation dynamics and human impacts on the vegetation of Upper Mun River floodplain, northeast Thailand. New Zealand Geographer 57(2):21-32.

Brink, Ole, Annie Vesterby, and Jørn Jensen

1998 Pattern of injuries due to interpersonal violence. Injury 29(9):705-709.

Buikstra, Jane E., and Douglas H. Ubelaker

1994 Standards for Data Collection from Human Skeletal Remains: Proceedings of a Seminar at the Field Museum of Natural History. Research Series No. 44. Fayetteville, AR: Arkansas Archaeological Survey.

Carter, Alison Kyra

2015 Beads, exchange networks and emerging complexity: A case study from Cambodia and Thailand (500 BCE-CE 500). Cambridge Archaeological Journal 25(4):733-757.

Castillo, C., C.F.W. Higham, K. Miller, N. Chang, K. Douka, T. Higham, and D. Fuller

2018 Social responses to climate change in Iron Age northeast Thailand: New archaeobotanical evidence. Antiquity 92(365):1274-1291.

Coupey, AnNe-Sophie

2008 Infant and child burials in the Samon valley, Myanmar, in Archaeology in Southeast Asia, from Homo Erectus to the Living Traditions: Choice of Papers from the 11th International Conference of the 
European Association of Southeast Asian Archaeologists, 25th-29th September 2006, Bougon, France: 119-125, ed. J.-P. Pautreau, A.-S. Coupey, V. Zeitoun, E. Rambault. European Association of Southeast Asian Archaeologists.

DOMETT, K. M., AND H. Buckley

2012 Large lytic cranial lesions: A differential diagnosis from pre-Angkorian Cambodia. International Journal of Osteoarchaeology 22(6):731-739.

DOMETt, K. M., AND D.J.W. O’Reilly

2009 Health in Pre-Angkorian Cambodia: A bioarchaeological analysis of the skeletal remains from Phum Snay. Asian Perspectives 48(1):56-78.

Domett, K. M., D.J.W. O’Reilly, And H. R. Buckley

2011 Bioarchaeological evidence for conflict in Iron Age north-west Cambodia. Antiquity 85:441-458.

Duke, Belinda J., Alison K. Carter, and Nigel J. Chang

2010 The excavation of Iron Age working floors and small-scale industry at Ban Non Wat, Thailand. Papers from the Institute of Archaeology 20:123-130.

Ehrlich, Edwin, and Helmut Maxeiner

2002 External injury marks (wounds) on the head in different types of blunt trauma in an autopsy series. Medicine and Law 21(4):773-782.

Evans, Caitlin, Nigel Chang, and Naho Shimizu

2016 Sites, survey, and ceramics: Settlement patterns of the first to ninth centuries CE in the Upper Mun River Valley, northeast Thailand. Journal of Southeast Asian Studies 47(3):438-467.

Eyre, Chureekamol Onsuwan

2010 Social variation and dynamics in metal age and protohistoric central Thailand: A regional perspective. Asian Perspectives 49(1):43-84.

Google Earth, Digital Globe

2016 Satellite view of the site of Non Ban Jak, northeast Thailand. Google Earth, Digital Globe image, retrieved 2 December 2017 from www.google.com/maps/@15.2584603,102. $1704658,519 \mathrm{~m} /$ data $=! 3 \mathrm{~m} 1 ! 1 \mathrm{e} 3$.

Gorman, Chester, and Pisit Charoenwongsa

1976 Ban Chiang: A mosaic of impressions from the first two years. Expedition 18(4):14.

Goulding, A., I. E. Jones, R. W. Taylor, P. J. Manning, and S. M. Williams

2000 More broken bones: A 4-year double cohort study of young girls with and without distal forearm fractures. Journal of Bone and Mineral Research 15(10):2011-2018.

Grauer, Anne L., and Charlotte A. Roberts

1996 Paleoepidemiology, healing, and possible treatment of trauma in the medieval cemetery population of St. Helen-on-the-Walls, York, England. American Journal of Physical Anthropology 100(4):531-544.

Halcrow, Siân E., Nathan J. Harris, Nancy Tayles, Rona Ikehara-Quebral, and Michael Pietrusewsky

2013 From the mouths of babes: Dental caries in infants and children and the intensification of agriculture in mainland Southeast Asia. American Journal of Physical Anthropology 150(3):409-420.

Harrod, Ryan P., Pierre Liénard, and Debra. L. Martin

2012 Deciphering violence in past societies: Ethnography and the interpretation of archaeological populations, in The Bioarchaeology of Violence: 63-80, ed. Debra L. Martin, Ryan P. Harrod, and Ventura R. Pérez. Tallahassee, Florida: University of Florida.

Hatch, Robert L., And Scott Hacking

2003 Evaluation and management of toe fractures. American Family Physician 68(12):2413-2418.

Higham, C.F.W

1998 The transition from Prehistory to the Historic Period in the Upper Mun Valley. International Journal of Historical Archaeology 2(3):235-260.

2002 Early Cultures of Mainland Southeast Asia. Chicago: Art Media Resources.

2011a The excavation of Ban Non Wat: IX Summary and conclusions, in The Origins of the Civilization of Angkor, Volume 4: The Excavation of Ban Non Wat. Part II: The Neolithic Occupation: 199-211, ed. C.F.W. Higham and A. Kijngam. Bangkok: Fine Arts Department of Thailand. 
$2011 b$ The Iron Age of the Mun Valley, Thailand. The Antiquaries Journal 91(September):101-144.

2013 Social change during the Bronze and Iron Ages of northeast Thailand, in Advancing Southeast Asian Archaeology: 270-278, ed. N. H. Tan. Bangkok: SEAMEO SPAFA Regional Centre for Archaeology and Fine Arts.

2014 From the Iron Age to Angkor: New light on the origins of a state. Antiquity 88(341):822-835.

$2016 a$ At the dawn of history: From Iron Age aggrandisers to Zhenla kings. Journal of Southeast Asian Studies 47(3):418-437.

$2016 b$ The prehistory of the Upper Mun Valley. Report to the National Research Council of Thailand and to the Fine Arts Department. Unpub. report archived at University of Otago, Dunedin, New Zealand.

Higham, C.F.W., Judith Cameron, Nigel Chang, Christina Castillo, Dougald O'Reilly, Fiona Petchey, and Louise Shewan

2014 The excavation of Non Ban Jak, northeast Thailand: A report on the first three seasons. Journal of Indo-Pacific Archaeology 34:1-41.

Higham, C.F.W., AND T. Higham

2009 A new chronological framework for prehistoric Southeast Asia, based on a Bayesian model from Ban Non Wat. Antiquity 83(319):125-144.

Higham, C.F.W., And A. Kijngam, eds.

2009 The excavation of Ban Non Wat. Vol. 3, The origins of the civilisation of Angkor. Bangkok: Fine Arts Department of Thailand.

Higham, C.F.W., A. Kijngam, and S. Talbot, eds.

2007 The Excavation of Noen U-Loke and Non Muang Kao. Vol. 2, The Origins of the Civilization of Angkor. Bangkok: Fine Arts Department of Thailand.

Higham, C.F.W., AND F. RisPOli

2014 The Mun Valley and Central Thailand in prehistory: Integrating two cultural sequences. Open Archaeology 1(1):2-28.

Higham, C.F.W., and R. Thosarat

1998 Prehistoric Thailand: From Early Settlement to Sukhothai. Bangkok: River Books.

Higham, C.F.W., and R. Thosarat, eds.

2005 The Excavation of Ban Lum Khao. The Origins of the Civilization of Angkor, vol. 1. Bangkok: Fine Arts Department of Thailand.

Higham, C.F.W., and R. Thosarat

2007 XVI: The burials of Noen U-Loke mortuary phase five, in The Excavation of Noen U-Loke and Non Muang Kao: 223-243, ed. C.F.W. Higham, A. Kijngam, and S. Talbot. The Origins of the Civilization of Angkor, vol. 2. Bangkok: Fine Arts Department of Thailand.

Hung, L. K., H. T. Wu, P. C. Leung, And L. Qin

2005 Low BMD is a risk factor for low-energy Colles' fractures in women before and after menopause. Clinical Orthopaedics and Related Research 435:219-225.

Joyce, Rosemary A.

1999 Social dimensions of Pre-Classic burials, in Social Patterns in Pre-Classic Mesoamerica: 15-48, ed. David C. Grove and Rosemary A. Joyce. Washington, D.C.: Dumbarton Oaks.

Judd, Margaret A.

2008 The parry problem. Journal of Archaeological Science 35(6):1658-1666.

Judd, Margaret A., And C. A. Roberts

1999 Fracture trauma in a medieval British farming village. American Journal of Physical Anthropology 109(2):229-243.

Jurmain, Robert, Eric J. Bartelink, Alan Leventhal, Viviana Bellifemine, Irina Nechayev,

Melynda Atwood, and Diane DiGiuseppe

2009 Paleoepidemiological patterns of interpersonal aggression in a prehistoric central California population from CA-ALA-329. American Journal of Physical Anthropology 139(4): 462-473.

Kanterewicz, E., A. Yanez, A. Perez-Pons, I. Codony, L. Del Rio, and A. Diez-Perez

2002 Association between Colles' fracture and low bone mass: Age-based differences in postmenopausal women. Osteoporosis International 13(10):824-828. 
King, Charlotte L., R. Alexander Bentley, Charles Higham, Nancy Tayles, Una Strand ViĐarsdóttir, Robert Layton, Colin G. Macpherson, and Geoff Nowell

2014 Economic change after the agricultural revolution in Southeast Asia? Antiquity 88(339): $112-125$

King, Charlotte L., R. Alexander Bentley, Nancy Tayles, Una Strand ViĐarddóttir, Geoff Nowell, and Colin G. Macpherson

2013 Moving peoples, changing diets: Isotopic differences highlight migration and subsistence changes in the Upper Mun River Valley, Thailand. Journal of Archaeological Science 40(4): 1681-1688.

KrakowKa, K.

2017 Violence-related trauma from the Cistercian Abbey of St Mary Graces and a Late Black Death cemetery. International Journal of Osteoarchaeology 27(1):56-66.

Kremer, Celia, Stephanie Racette, Charles-Antoine Dionne, and Anny Sauvageau

2008 Discrimination of falls and blows in blunt head trauma: Systematic study of the hat brim line rule in relation to skull fractures. Journal of Forensic Sciences 53(3):716-719.

Kuijt, Ian, Emma Guerrero, Miquel Molist, and Josep Anfruns

2011 The changing Neolithic household: Household autonomy and social segmentation, Tell Halula, Syria. Journal of Anthropological Archaeology 30(4):502-522.

Lessa, A., AND S. M. SOUZA

2006 Broken noses for the gods: Ritual battles in the Atacama Desert during the Tiwanaku period. Memórias do Instituto Oswaldo Cruz 101(S2):133-138.

LEWIS, JASON E.

2008 Identifying sword marks on bone: Criteria for distinguishing between cut marks made by different classes of bladed weapons. Journal of Archaeological Science 35(7):2001-2008.

LOVejoy, C. Owen

1985 Dental wear in the Libben population: Its functional pattern and role in the determination of adult skeletal age at death. American Journal of Physical Anthropology 68(1):47-56.

LOVELL, NANCY C.

1997 Trauma analysis in paleopathology. American Journal of Physical Anthropology 104(S25):139-170.

2008 Analysis and interpretation of skeletal trauma, in Biological Anthropology of the Human Skeleton: 341-386, ed. M. Anne Katzenberg and Shelley R. Saunders. Hoboken, NJ: John Wiley \& Sons.

Martin, Debra L.

2008 Reanalysis of trauma in the La Plata Valley (900-1300): Strategic social violence and the bioarchaeology of captivity, in Reanalysis and Reinterpretation in Southwestern Bioarchaeology: 167-184, ed. A.L.W. Stodder. Tempe: Arizona State University.

Martin, Debra L., Nancy J. Akins, Bradley J. Crenshaw, and Pamela K. Stone

2008 Inscribed on the body, written in the bones: The consequences of social violence at La Plata, in Social Violence in the Prehispanic American Southwest: 98-122, ed. D. L. Nichols and P. L. Crown. Tucson: University of Arizona Press.

Martin, Debra L., and Ryan P. Harrod

2012 Body parts and parts of bodies: Traces of violence in past cultures. International Journal of Paleopathology 2(2):49-52.

Martin, Debra L., Ryan P. Harrod, and Misty Fields

2010 Beaten down and worked to the bone: Bioarchaeological investigations of women and violence in the ancient Southwest. Landscapes of Violence 1(1-3):1-19.

Milner, G. R., J. L. Boldsen, S. Weise, J. M. Lauritsen, and U. H. Freund

2015 Sex-related risks of trauma in medieval to early modern Denmark, and its relationship to change in interpersonal violence over time. International Journal of Paleopathology 9:59-68.

Murphy, Colin G., Ciara M. McGuire, Natasha O’Malley, and Paul Harrington

2010 Cow-related trauma: A 10-year review of injuries admitted to a single institution. Injury 41(5):548-550.

Murphy, Stephen A.

2014 Buddhism and its relationship to Dvaravati period settlement patterns and material culture in northeast Thailand and central Laos c. sixth-eleventh centuries AD: A historical ecology approach to the landscape of the Khorat Plateau. Asian Perspectives 52(2):300-325. 
Nirula, Raminder, Jose J. Diaz, Donald D. Trunkey, and John C. Mayberry

2009 Rib fracture repair: Indications, technical issues, and future directions. World Journal of Surgery 33(1):14-22.

NORRIS, FRAN H.

1992 Epidemiology of trauma: Frequency and impact of different potentially traumatic events on different demographic groups. Journal of Consulting and Clinical Psychology 60(3):409.

Nowak, Jan, Hans Mallmin, and Sune Larsson

2000 The aetiology and epidemiology of clavicular fractures. Injury 31(5):353-358.

Nunn, D., G. J. Taylor, and F. W. Heatley

1989 Fractures and dislocations of the clavicle. Current Orthopaedics 3(4):255-261.

Ocobock, Paul

2012 Spare the rod, spoil the colony: Corporal punishment, colonial violence, and generational authority in Kenya, 1897-1952. International Journal of African Historical Studies 45(1):29-56.

O’Neill, T. W., D. Marsden, J. E. Adams, and A. J. Silman

1996 Risk factors, falls, and fracture of the distal forearm in Manchester, UK. Journal of Epidemiology \& Community Health 50(3):288-292.

Onsuwan, Chureekamol

2008 Metal Age complexity in Thailand: Socio-political development and landscape use in the upper Chao Praya basin. Bulletin of the Indo-Pacific Prehistory Association 23:7-14.

O’Reilly, D.J.W.

1998 The discovery of clay-lined floors at an Iron Age site in Thailand: Preliminary observations from Non Muang Kao, Nakhon Ratchasima province. Journal of The Siam Society 85(1):1-14.

2000 From the Bronze Age to the Iron Age in Thailand: Applying the heterarchical approach. Asian Perspectives 39(1-2):1-19.

2014 Increasing complexity and the political economy model: A consideration of Iron Age moated sites in Thailand. Journal of Anthropological Archaeology 35:297-309.

O’Reilly, D.J.W., T. Chanthourn, and K. Domett

2004 A preliminary report on the excavation of an Iron Age Cemetery at Phum Snay, Banteay Meanchey, Cambodia, 2003. UDAYA: Journal of Khmer Studies 5:219-225.

Osterholtz, Anna J.

2012 The social role of hobbling and torture: Violence in the prehistoric Southwest. International Journal of Paleopathology 2(2):148-155.

OWens, LaWrence S.

2007 Craniofacial trauma in the Prehispanic Canary Islands. International Journal of Osteoarchaeology 17(5):465-478.

Pietrusewsky, Michael, and Michele T. Douglas

2001 Intensification of agriculture at Ban Chiang: Is there evidence from the skeletons? Asian Perspectives 40(2):157-178.

Pijoan Aguadé, C. M., and J. M. Lory

1997 Evidence for human sacrifice, bone modification, and cannibalism in Ancient Mexico, in Troubled Times: Violence and Warfare in the Past: 217-239, ed. D. L. Martin and D. W. Frayer. Amsterdam: Gordon and Breach.

Richards, Todd A., ANd D. Nicole DeAL

2014 Distal ulna fractures. Journal of Hand Surgery 39(2):385-391.

Roberts, C. A.

2000 Trauma in biocultural perspective: Past, present and future work in Britain, in Human Osteology in Archaeology and Forensic Science: 337-356, ed. Margaret Cox and Simon Mays. Cambridge: Cambridge University Press.

Roksandic, Mirjana, Marija Djurić, Zoran Rakočević, and Kimberly Seguin

2006 Interpersonal violence at Lepenski Vir Mesolithic/Neolithic complex of the Iron Gates Gorge (Serbia-Romania). American Journal of Physical Anthropology 129(3):339-348.

Scott, Rachel M., and Hallie R. Buckley

2014 Exploring prehistoric violence in Tonga: Understanding skeletal trauma from a biocultural perspective. Current Anthropology 55(3):335-347. 
SHAFFER, L. JEN

2017 An anthropological perspective on the climate change and violence relationship. Current Climate Change Reports 3(4):222-232.

SigURDARDOTTIR, K.

2014 Epidemiology, in Distal Radius Fractures: Current Concepts: 37-44, ed. L. M. Hove, T. Lindau, and P. Holmer. New York: Springer.

Šlaus, Mario, Mario Novak, Željka Bedić, and Davor Strinović

2012 Bone fractures as indicators of intentional violence in the Eastern Adriatic from the antique to the late Medieval Period (2nd-16th century AD). American Journal of Physical Anthropology 149(1):26-38.

SмIтн, B. H

1984 Patterns of molar wear in hunter-gatherers and agriculturalists. American Journal of Physical Anthropology 63(1):39-56.

STeinmetz, SuZANne K.

1986 The violent family, in Violence in the Home: Interdisciplinary Perspectives: 51-67, ed. Mary Lystad. Philadelphia: Brunner Mazel.

TAyles, Nancy

2003 Murder or mortuary behaviour? An Iron Age enigma from Northeast Thailand. International Journal of Osteoarchaeology 13(4):197-206.

Tayles, Nancy, Sian Halcrow, and Kathr yn Domett

2007 The people of Noen U-Loke, in The Origins of the Civilization of Angkor. Volume 2: The Excavation of Noen U-Loke and Non Muang Kao: 243-304, ed. C.F.W. Higham and A. Kijngam. Bangkok: Fine Arts Department, Thailand.

Torres-Rouff, Christina, and Laura M. King

2014 Face me like a man! (or, like a woman): Antemortem nasal fractures in pre-Columbian San Pedro de Atacama, in Bioarchaeological and Forensic Perspectives on Violence: How Violent Death is Interpreted from Skeletal Remains: 134-146, ed. Debra L. Martin and Cheryl P. Anderson. Cambridge: Cambridge University Press.

Totten, Samuel, William S. Parsons, and Israel W. Charny, eds

1997 Century of Genocide: Eyewitness Accounts and Critical Views. New York: Garland.

TUNG, T. A.

2014 Gender based violence in the Wari and Post-Wari Era of the Andes, in The Routledge Handbook of the Bioarchaeology of Human Conflict: 333-354, ed. Christopher Knüsel and Martin J. Smith. London: Routledge.

Van Vliet-Koppert, Sabine T., Hamit Cakir, Esther M. M. Van Lieshout, Mark R. De Vries, MaArten Van Der Elst, and Tim Schepers

2011 Demographics and functional outcome of toe fractures. Journal of Foot and Ankle Surgery 50(3):307-310.

VICKERY, MiCHAEL

1998 Society, Economics, and Politics in Pre-Angkor Cambodia: The 7th-8th Centuries. Tokyo: Centre for East Asian Cultural Studies for UNESCO.

Virtanen, Simo V., Veijo Notkola, Ritva Luukkonen, Erkki Eskola, and Kari Kurppa

2003 Work injuries among Finnish farmers: A national register linkage study 1996-1997. American Journal of Industrial Medicine 43(3):314-325.

WALKER, P. L.

1989 Cranial injuries as evidence of violence in prehistoric southern California. American Journal of Physical Anthropology 80(3):313-323.

2001 A bioarchaeological perspective on the history of violence. Annual Review of Anthropology 30:573-596.

2014 Wife beating, boxing, and broken noses: Skeletal evidence for the cultural patterning of violence, in Troubled Times: Violence and Warfare in the Past: 145-178, ed. D. W. Frayer and D. L. Martin. London: Routledge.

Ward, Stacey, and Nancy Tayles

2016 Cremation in mainland Southeast Asia: An overview, in The Routledge Handbook of Bioarchaeology in Southeast Asia and the Pacific Islands: 239-256, ed. Marc Oxenham and Hallie R. Buckley. Abingdon, England: Routledge. 
Watts, Martin, and Ethan M. Meisel

2011 Cattle associated trauma: A one year prospective study of all injuries. Injury 42(10):1084-1087.

WELCH, D. J.

1985 Adaptation to Environmental Unpredictability: Intensive Agriculture and Regional Exchange at Late Prehistoric Centers in the Phimai Region, Thailand. Ph.D. diss. University of Hawai'i.

Welch, D. J., AND J. R. McNeill

1988 Excavations at Ban Tamyae and Non Ban Kham, Phimai Region, Northeast Thailand. Asian Perspectives 28(2):99-123.

Wheatley, Bruce P.

2008 Perimortem or postmortem bone fractures? An experimental study of fracture patterns in deer femora. Journal of Forensic Sciences 53(1):69-72.

White, Joyce C.

1995 Incorporating heterarchy into theory on socio-political development: The case from Southeast Asia. Archeological Papers of the American Anthropological Association 6(1):101-123.

2017 Changing paradigms in Southeast Asian Archaeology. Journal of Indo-Pacific Archaeology 41:66-77.

Wilkinson, R. G., AND K. M. Van Wagenen

1993 Violence against women: Prehistoric skeletal evidence from Michigan. Midcontinental Journal of Archaeology 18(2):190-216.

Wohlfarth, Barbara, Charles Higham, Kweku Afrifa Yamoah, Akkaneewut Chabangborn, Sakonvan Chawchai, and Rienk H SmitTenberg

2016 Human adaptation to mid-to late-Holocene climate change in Northeast Thailand. The Holocene 26(11):1875-1886.

WHO [World Health Organisation]

1996 Violence: A public health priority, in World Health Organisation Global Consultation on Violence and Health. Geneva: World Health Organisation.

Xiang, Huiyun, Zengzhen Wang, lorann Stallones, Thomas J. Keefe, Xuzhen Huang, and XiANGHUA Fu

2000 Agricultural work-related injuries among farmers in Hubei, People's Republic of China. American Journal of Public Health 90(8):1269-1276. 